\title{
Weather radar rainfall data in urban hydrology
}

\author{
Søren Thorndahl ${ }^{1}$, Thomas Einfalt ${ }^{2}$, Patrick Willems ${ }^{3}$, Jesper Ellerbæk Nielsen ${ }^{1}$, Marie-Claire ten Veldhuis ${ }^{4}$, \\ Karsten Arnbjerg-Nielsen ${ }^{5}$, Michael R. Rasmussen ${ }^{1}$, and Peter Molnar ${ }^{6}$ \\ ${ }^{1}$ Department of Civil Engineering, Aalborg University, Aalborg, 9220, Denmark \\ ${ }^{2}$ hydro \& meteo GmbH \& Co KG, 23552 Lübeck, Germany \\ ${ }^{3}$ Department of Civil Engineering, KU Leuven, Leuven, 3001, Belgium \\ ${ }^{4}$ Department of Water Management, Delft University of Technology, Delft, 2628 CN, the Netherlands \\ ${ }^{5}$ Department of Environmental Engineering, Technical University of Denmark, Lyngby, 2800, Denmark \\ ${ }^{6}$ Institute of Environmental Engineering, ETH Zurich, Zurich, 8093, Switzerland
}

Correspondence to: Søren Thorndahl (st@ civil.aau.dk)

Received: 30 September 2016 - Discussion started: 6 October 2016

Revised: 8 February 2017 - Accepted: 17 February 2017 - Published: 7 March 2017

\begin{abstract}
Application of weather radar data in urban hydrological applications has evolved significantly during the past decade as an alternative to traditional rainfall observations with rain gauges. Advances in radar hardware, data processing, numerical models, and emerging fields within urban hydrology necessitate an updated review of the state of the art in such radar rainfall data and applications. Three key areas with significant advances over the past decade have been identified: (1) temporal and spatial resolution of rainfall data required for different types of hydrological applications, (2) rainfall estimation, radar data adjustment and data quality, and (3) nowcasting of radar rainfall and real-time applications. Based on these three fields of research, the paper provides recommendations based on an updated overview of shortcomings, gains, and novel developments in relation to urban hydrological applications. The paper also reviews how the focus in urban hydrology research has shifted over the last decade to fields such as climate change impacts, resilience of urban areas to hydrological extremes, and online prediction/warning systems. It is discussed how radar rainfall data can add value to the aforementioned emerging fields in current and future applications, but also to the analysis of integrated water systems.
\end{abstract}

\section{Introduction}

In 2003 the International Group on Urban Rainfall (IGUR) under the IWA/IAHR Joint Committee on Urban Drainage initiated joint work on the status and development on using radar rainfall data within the context of urban drainage. This led to a review paper entitled "Towards a roadmap for use of radar rainfall data in urban drainage" which was published in Journal of Hydrology by Einfalt et al. (2004). The paper highlighted the state of the art at the time in weather radar hardware and data processing, as well as methods and challenges in the application of radar rainfall data in urban drainage.

However, the foundation upon which the original paper was based has significantly changed during the past 1.5 decades. This is partly due to the rapid developments in radar hardware, signal and data processing; the development of new methods for data processing and analysis; advancements in urban runoff modelling incorporating more complex hydrological processes, etc.

The purpose of the current paper remains the same as the one by Einfalt et al. (2004), i.e. to bridge the gap between current precipitation measurements and suitable precipitation information for operation and design of urban drainage systems. Schilling (1991) and Einfalt et al. (2004) summarized these needs as follows: at least 20 years of recordings without data gaps, a volumetric accuracy of less than $3 \%$, and a spatio-temporal resolution of $1 \mathrm{~km}^{2}$ and $1 \mathrm{~min}$, respectively. Where Einfalt et al. (2004) used the term "ur- 
ban drainage" we extend the terminology to "urban hydrology". Thereby, we do not only encounter design, analysis, and management of urban drainage systems, but also urban hydrological modelling/prediction as well as management of and interaction between different parts of the whole urban water cycle, i.e. urban drainage systems, flood prone areas, rivers and streams, and groundwater.

The scientific interest within the field is evident from the number of publications with specific search strings in different scientific databases. Figure 1 shows the number of publications registered under the keywords "radar + urban drainage" and "radar + urban hydrology" in the databases Scopus (Elsevier) and Web of Science (Thomson Reuters) for each year in the period 1980-2015. Out of a total of 142 published papers in Scopus with keywords "radar+urban drainage", 37 are from 2004 and earlier and 105 are published after 2004. The corresponding numbers for the keywords "radar + urban hydrology" are 56 before 2004 and 85 after 2004. Searching for "hydrology" in general in the aforementioned databases shows a somewhat linear growth from 1980 to 2015 (not shown), whereas the increase in the number of publications within "radar + urban drainage" and "radar + urban hydrology" is more exponential, which indicates a faster growth with regards to the latter. This significant growth covers both an increase in applications of weather radar data in urban hydrology, but also continuous improvement and development of methods, algorithms, instrumentation, etc., for estimating rainfall from radar data.

Table 1 presents the three most cited papers according to Scopus and Web of Science with the keywords "radar + urban drainage". Both Schilling (1991) and Einfalt et al. (2004) are review papers providing recommendations on the use of radar data within urban hydrology. The reason for the many citations should probably be found in a need for guidelines in terms of data resolution, rainfall estimation, and applications. Both papers provide a look into the future of radar rainfall in urban hydrology, and emphasize that the application of radar rainfall is under development and that the examples of applications are rather sparse. Einfalt et al. (2004) list a wide range of hydrological applications showing the clear potential for the use of radar data. Since 2004, many such hydrological applications have been implemented and tested in both innovation/research projects and in operational applications. This paper will therefore provide an updated overview of some of the listed potential hydrological applications from Einfalt et al. (2004) and their current status in terms of documented applications.

Climate change and consequently increase in extreme rainfall have been a significant catalyst for the development in urban hydrological models over the past decade. There is a need to be able to simulate current and future loads on drainage systems and to fully utilize the capacity of drainage systems in order to accommodate climate change. Furthermore, integrated hydrological models (e.g. integrated urban drainage, river, and inundation models) have become stan- dard tools, e.g. to simulate inundation risks in urban areas. The use of more detailed and distributed models increased the demand for good quality, high resolution inputs, which promotes the use of radar rainfall data in urban hydrology.

In addition to the higher demand for precise local rainfall data, technological developments in hardware as well as data processing and quality have changed significantly since the publication of the papers in Table 1. These form the starting basis of this paper, which aims to provide a review of the major technical developments during the past decade, with particular focus on the most ground-breaking applications and cases, from where updated recommendations are distilled for the applications of radar rainfall data in urban hydrology. Given that many of the new developments are still within innovation projects by research communities, this review also aims to expand the new knowledge to the industry and water companies. Confidence in radar data is provided and possibilities of applications in urban hydrology and urban drainage are being mapped.

We structure the review based on the following three key areas of research that are identified as being central in a large majority of the publications within the field of radar rainfall application in urban hydrology.

- Temporal and spatial resolution of radar data (Sect. 2.1)

- Rainfall estimation, radar data adjustment, and quality (Sect. 2.2)

- Nowcasting of radar rainfall (Sect. 2.3)

We approach these key areas from two sides. Initially, in Sect. 3, we review the state of the art within the three key areas, respectively, focusing on the radar and radar rainfall related issues. Secondly, we will end each sub-section by reviewing the impacts of each of the key areas on applications within urban hydrological modelling. The second part of the paper focuses on the value of applying radar rainfall in urban hydrology, giving examples of applications (Sect. 3). Finally, in Sect. 4, we present our subjective views of what is needed and what can be recommended for current and future applications of radar rainfall data in urban hydrology.

\section{State of the art in radar rainfall estimation for urban hydrological applications}

Urban hydrology is characterized by fast runoff and short response times on impervious surfaces, and thus small timescales and space scales compared to rural hydrology. Rainfall data for urban hydrology are therefore required to resolve these spatial and temporal scales sufficiently. However, following Willems (2001), Thorndahl et al. (2008), Schellart et al. (2012b), and others, the errors in such rainfall input data are one of the most important sources of uncertainty in (urban) hydrological models. For example, for a sewer system model in Belgium, it was shown by Willems 


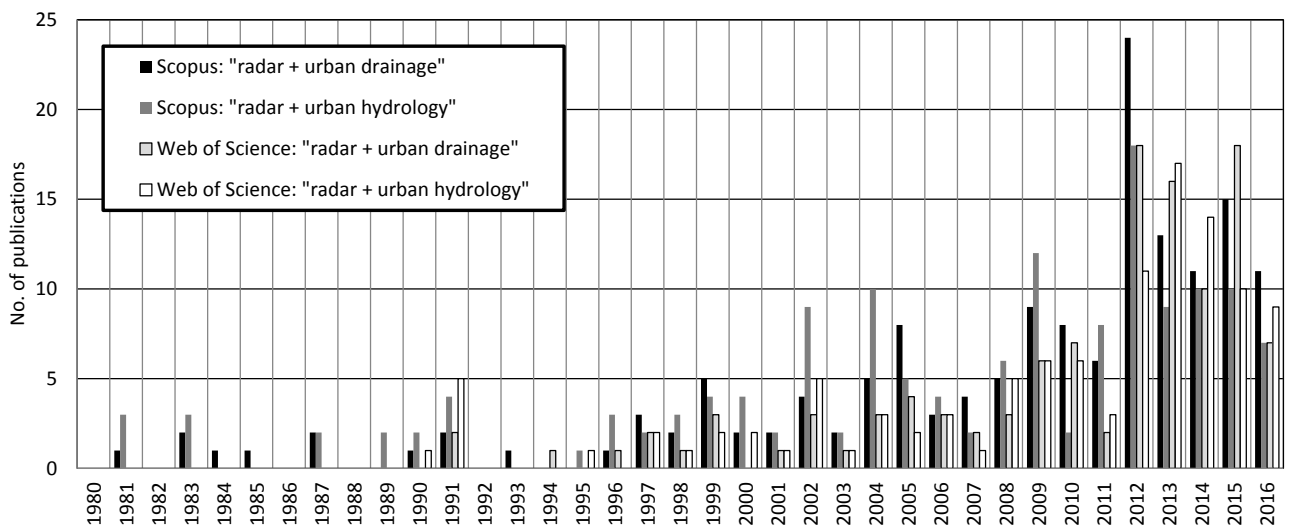

Figure 1. Scopus and Web of Science documents under search strings "radar + urban drainage" and "radar + urban hydrology".

Table 1. Most cited papers within radar and urban drainage.

\begin{tabular}{llrr}
\hline & Paper title & Citations Scopus* & Citations Web of Science* \\
\hline Einfalt et al. (2004) & $\begin{array}{l}\text { Towards a roadmap for use of radar rainfall data in ur- } \\
\text { ban drainage }\end{array}$ & 94 \\
Smith et al. (2002) & $\begin{array}{l}\text { The Regional Hydrology of Extreme Floods in an Ur- } \\
\text { banizing Drainage Basin } \\
\text { Rainfall data for urban hydrology: what do we need? }\end{array}$ & 85 \\
Schilling (1991) & Rair & 81 \\
\hline
\end{tabular}

* As of 1 February 2017.

and Berlamont (1999) that about $20 \%$ of the total uncertainty in the downstream sewer throughflow discharges could be explained by the spatial variability of the rainfall and about $20-25 \%$ by the rainfall measurement errors, consisting in their case of rain gauge calibration errors, rainfall intensity resolution errors and errors by wind and local disturbances. For extreme events, e.g. flash flooding, uncertainties related to spatial variability and rainfall measurement errors are expected to be even larger (e.g. Berne et al., 2004; Hossain et al., 2004; Brauer et al., 2016). Hence there is a need for high quality and high resolution rainfall inputs into urban hydrological models in order to reduce uncertainty in hydrological responses. Radar rainfall data are ideal in that respect.

Since the first use of radars for precipitation measurement, there has been rapid development and improvement of weather radar hardware, signal processing, software, etc., but the fundamental principles of applying weather radar for precipitation measurements have not changed significantly. We therefore refer to the existing literature on the fundamentals of radar and atmosphere physics, e.g. antennas, frequencies, bandwidths, polarization, and data correction, e.g. attenuation, clutter removal, and reflectivity-rainfall conversion. These fundamentals are indeed crucial for the quality of rainfall estimation and should definitely not be disregarded by users of radar rainfall, but they are omitted from the paper since they have been discussed in depth in primers such as Doviak and Zrnić (1993), Collier (1996), Bringi and Chan- drasekar (2001), Meischner (2004), Michaelides (2008), and Rinehart (2010). Furthermore, there are pioneering and significant journal papers such as Marshall and Palmer (1945), Austin and Austin (1974), Wilson and Brandes (1979), Smith and Krajewski (1991), Krajewski and Smith (2002), Einfalt et al. (2004), Delrieu et al. (2009), Krajewski et al. (2010), Villarini and Krajewski (2010), and Berne and Krajewski (2013) which also provide general information on specifications and applications of radar rainfall. Also, VDI (2014) and ISO (2017) have produced a standard on precipitation measurement by radar. In the following, we focus on new developments in applications of radar in urban hydrology, and start the discussion from the temporal and spatial resolution needs.

\subsection{Temporal and spatial resolution of radar data}

\subsubsection{Temporal resolution}

The temporal resolution of radar data is governed by the scanning strategy of the radar. A radar scanning the atmosphere in different elevations to generate a full azimuthal volume scan can take up to several minutes depending on rotational speed and the number of scanning elevations. Radar collects instantaneous samples of rain rates (estimated from reflectivities), unlike rain gauges, which accumulate rainfall over a given time interval. Some radars operate with intermediate dedicated Doppler scans for each volume scan, hence 
Table 2. Typical operating resolutions and maximum ranges for different types of weather radars used in hydrological applications.

\begin{tabular}{lrrr}
\hline & X-band & C-band & S-band \\
\hline Spatial resolution & $100-1000 \mathrm{~m}$ & $250-2000 \mathrm{~m}$ & $1000-4000 \mathrm{~m}$ \\
Temporal resolution & $1-5 \mathrm{~min}$ & $5-10 \mathrm{~min}$ & $10-15 \mathrm{~min}$ \\
Maximum quantitative & $30-60 \mathrm{~km}$ & $100-130 \mathrm{~km}$ & $100-200 \mathrm{~km}$ \\
range & & & \\
\hline
\end{tabular}

doubling the time between two consecutive reflectivity scans. Operational meteorological S-,C-, and X-band radars usually provide reflectivity scans with a temporal resolution of 515 min (Table 2), whereas research radars dedicated to high resolution rainfall monitoring in specific areas and specific elevations are reported to provide data resolutions down to 15 s (e.g. van de Beek et al., 2010; Mishra et al., 2016).

\subsubsection{Spatial resolution}

The main strength of radars for rainfall estimation is their capability to provide spatially distributed rainfall information. The spatial resolution of radar rainfall data is basically determined by the hardware and physics. The radial resolution (or range resolution) is a function of the pulse length (in principle the range resolution is equal to half the pulse length, Battan, 1973) and can thus be very small for all radar bandwidths. However, for operational radars the radial resolution is often an indirect function of the maximum unambiguous radar range due to storage and data transmission restrictions. Thus, each radar scanline is subdivided into a fixed/selected number of range bins, which eventually determines the range resolution of the data. For pulsed radars, the number of range bins is determined by the ratio of the maximum unambiguous range and the range resolution (i.e. half the pulse length). $\mathrm{X}$-band radars with a shorter range than C-and S-band radars are therefore typically operated with a finer radial resolution, e.g. down to a minimum of $500 \mathrm{~m}$. Radial resolutions between 3 and $100 \mathrm{~m}$ have been documented by e.g. Leijnse et al. (2010), van de Beek et al. (2010), Lengfeld et al. (2014), and Mishra et al. (2016).

The spatial resolution also depends on the azimuthal (or angular) horizontal resolution, which is a function of the beam width determined by the size and design of the antenna. In contrast to the radial resolution, the azimuthal resolution decreases as a function of the radial distance from the radar. Most operational weather radars use parabolic dish antennas with a beam width of approx. $1^{\circ}$, thus functioning with an azimuthal horizontal resolution close to $1^{\circ}$ (http://www.eumetnet.eu/opera). As an example, a distance of $100 \mathrm{~km}$ from the radar will thus lead to a width of the beam of $\sim 1750 \mathrm{~m}$. Small local X-band radars with (non-parabolic) horizontal fan beam antennas typically have larger opening angles between 2 and $3^{\circ}$, but also a smaller maximum range compared to meteorological radars due to integration of rain- fall over a large vertical distance (Pedersen et al., 2010a, b; Nielsen et al., 2012; Thorndahl and Rasmussen, 2012; Goormans and Willems, 2013; Nielsen et al., 2013; Borup et al., 2016).

Typical values for spatial resolutions and maximum ranges for operational radars are provided in Table 2. Generally, operational X-band radars function with both higher spatial and temporal resolutions than C- and S-band radars. This is typically because $\mathrm{X}$-band radars require smaller antennas than $\mathrm{C}$ - and S-band radars to achieve the same angular resolution. There are, however, examples of configurations of C- and S-band radars where high resolution data are derived. Such super resolution can be achieved by shortening the pulse lengths to obtain higher range resolutions (e.g. Seo and Krajewski, 2010; Sharif and Ogden, 2014; Ochoa Rodriguez et al., 2015) or applying adaptive scanning strategies to capture the most intensive part of a storm with a high degree of detail (e.g. Dolan and Rutledge, 2010).

Examples of radar reflectivity with four different spatial resolutions covering an area $(\sim 12 \mathrm{~km} \times 12 \mathrm{~km})$ over the city of Aalborg, Denmark, are shown in Fig. 2. The example illustrates the importance of high spatial resolution data in order to capture the spatial variability of rainfall over an urban area.

\subsubsection{Projection of data}

Many applications of radar data in urban hydrology favour projected Cartesian (gridded) over polar data with decreasing resolution as a function of range. The limit for generating high resolution Cartesian data is mainly related to the azimuthal resolution and thus range. Two common methods of data projection are (1) the Constant Altitude Plan Position Indicator (CAPPI) in which scans at different elevation angles (comprising one volume scan) are merged in order to generate a radar product with altitude independent of range (however, with an inhomogeneous zone with changing from one elevation to the next one), and (2) the Plan Position Indicator (PPI) that applies one scan elevation only, and that thus has an increasing altitude as a function of range.

Due to the curvature of the earth, the refraction of the radar beam through the atmosphere, and wind drift of the raindrops, assigning a radar measurement to a specific point on the surface can be quite challenging. This should also be considered when working with high spatial resolution radar data, since it is not certain that the rain can be allocated with the same accuracy at ground level as at a specific elevation.

\subsubsection{Advection interpolation (temporal downscaling)}

In order to increase the temporal resolution of operational meteorological radar data, especially for urban hydrological applications, some authors have developed methods to interpolate between radar images (Fabry et al., 1994; Atencia et al., 2011; Jasper-Tönnies and Jessen, 2014; Nielsen 

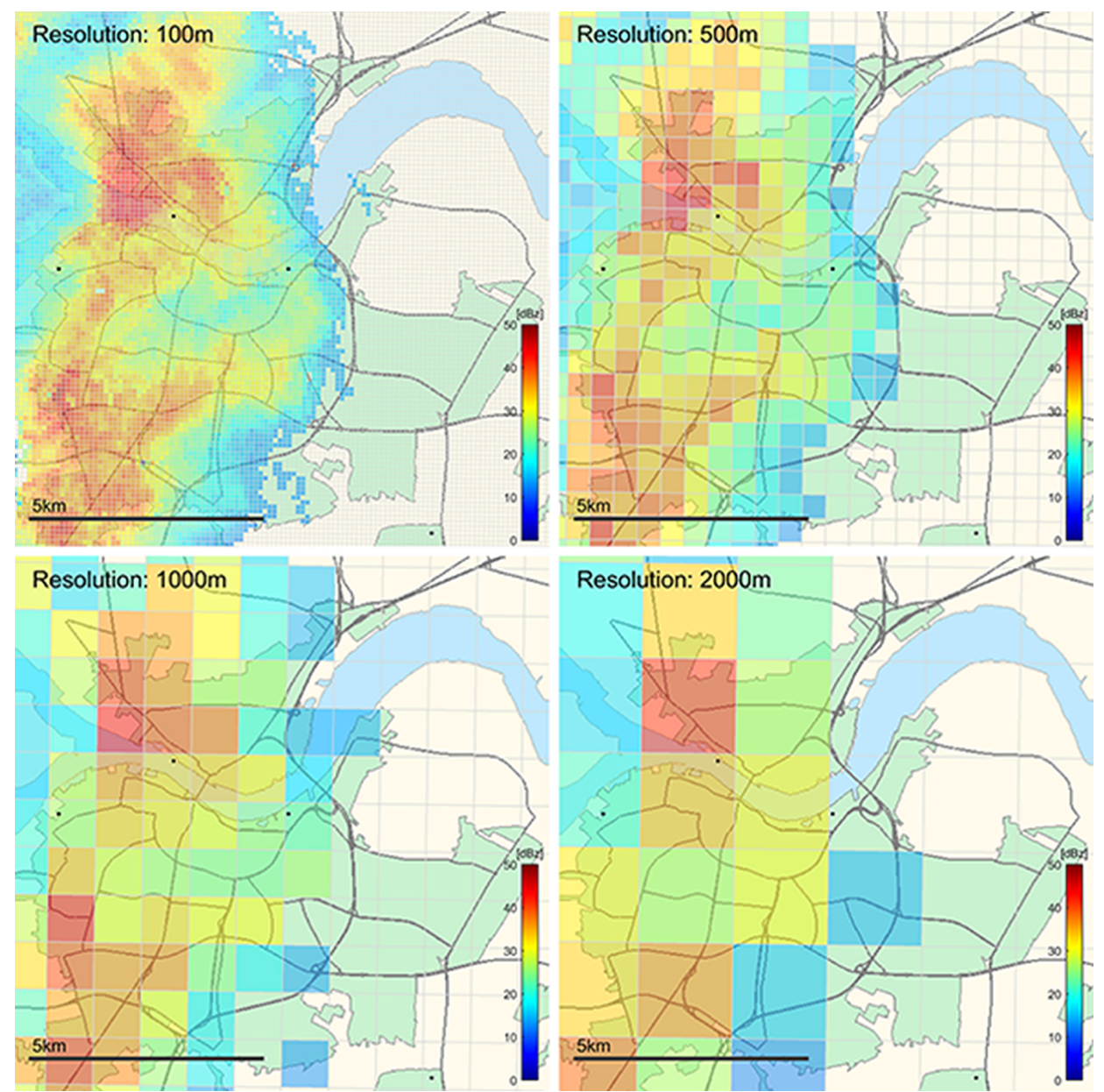

Figure 2. Example of radar reflectivity at four different Cartesian spatial resolutions over Aalborg, Denmark (lat: 57.05; lon: 9.92). The radar data are acquired with a Furuno WR-2100 dual-polarimetric X-band radar (Nielsen et al., 2015) at 1 min temporal resolution at 16:20:00 UTC on 25 July 2016. Black circles are rain gauges of the Danish Water Pollution Committee network.

et al., 2014a; Thorndahl et al., 2014b; Wang et al., 2015a). The governing principle in these downscaling methods is to apply the advection field of the rain, and, by resampling in space, convert the spatial resolution into temporal resolution. The methods have been proven to give better local peak estimates of rainfall intensities as well as more accurate accumulated quantitative precipitation estimates in comparison with point ground observations. Jasper-Tönnies and Jessen (2014), Nielsen et al. (2014a), Seo and Krajewski (2015), and Wang et al. (2015a) have successfully converted data with a 5 or $10 \mathrm{~min}$ resolution into a product with 1 min resolution for use in urban hydrological modelling. The concept of advection interpolation works if the raw radar data are instantaneous. If radar data are averaged (by multiple scans) over a time period, advection interpolation will not be favourable and temporal resolution cannot be increased. In relation to urban hydrological modelling, where very fine temporal resolution indeed is needed for some applications (e.g. down to $1 \mathrm{~min}$ ), the radar data based on instantaneous sampling are therefore preferable.

Considering the advective nature of rain, it is also clear that advection interpolation yields a better estimate of the area precipitation. Accumulation of instantaneous radar data with e.g. a 10 min sampling rate might result in a "fishbone" pattern consisting of periodical variability in rainfall accumulations. This is a result of the advection of rainfall between consecutive radar scans.

Commercial radar rainfall products (see Sect. 2.2.3) often provide data that are temporally accumulated or averaged; hence, a coarser temporal resolution of data can be found in these products.

\subsubsection{Impacts of temporal and spatial resolution of radar data in hydrological modelling}

In the literature, the impact of spatial and temporal radar data resolutions on hydrological model responses has been studied intensively (Quirmbach and Schultz, 2002; Berne et al., 
2004; Villarini et al., 2010; Emmanuel et al., 2012b; Gires et al., 2012; Liguori et al., 2012; Nielsen et al., 2012; Schellart et al., 2012b; Vieux and Imgarten, 2012; Gires et al., 2013; Lobligeois et al., 2014; Bruni et al., 2015; Gires et al., 2014b; Ochoa-Rodriguez et al., 2015; Rafieeinasab et al., 2015; Wang et al., 2015a; Thorndahl et al., 2016). Other than different spatial and temporal resolutions of radar rainfall input data, these studies represent a vast variety of different types, severity and number of events, radar types, catchment sizes, shapes and slopes, catchment imperviousness, models, model scales and resolutions (fully distributed, semidistributed or lumped), model outputs (e.g. peak flows, water levels, volumes, combined sewer overflow (CSO) discharges, volumes, frequencies, inundation levels), objective functions for evaluating and comparing results, etc. For these reasons, it is hard to formulate general conclusions on the impacts of the spatial and temporal data resolutions, since they largely depend on the studied set-up. However, three significant findings could be identified related to the requirements for spatial and temporal resolutions in runoff response modelling.

1. For increasing catchment sizes, the demand for high spatial and temporal resolution radar rainfall data decreases.

Schilling (1991) and Einfalt et al. (2004) recommended a minimum temporal resolution of $1-5 \mathrm{~min}$ and a minimum spatial resolution of $1 \mathrm{~km}$ for the application of radar data in urban hydrology in general. Berne et al. (2004) detailed this to $\sim 1 \mathrm{~min} / 2 \mathrm{~km}$ for 10 ha catchments, $\sim 3 \mathrm{~min} / 3 \mathrm{~km}$ for 100 ha catchments, and $\sim 6 \mathrm{~min} / 4 \mathrm{~km}$ for 1000 ha catchments. For even smaller catchments with an area of 1 ha or less, recent studies by Ochoa-Rodriguez et al. (2015) suggest a minimum resolution of $1 \mathrm{~min} / 100 \mathrm{~m}$.

2. Catchment characteristics and modelled runoff response play an important role in defining the required temporal and spatial radar data resolution.

The concentration time of the urban catchment or to a point of interest in the system are of importance and affected by many factors. According to the rational method (Kuichling, 1889), increasing concentration times will lead to greater critical rainfall aggregation levels (in this case coarser temporal resolution). Due to the dependence between temporal and spatial resolutions described above, increasing concentration times will reduce the demands for high spatial resolution. Thus, high space-time resolution is required for the simulation of peak runoff responses (surcharge, local flooding, etc.) upstream in an urban system. However, for the simulation of total catchment runoff or basin storage, the requirements on resolution may be reduced (Berne et al., 2004; Bruni et al., 2015; Rafieeinasab et al., 2015).
3. Storm characteristics (size, movement, shape, lifespan, intensity, etc.) can be important when choosing the spatial and temporal resolutions.

The ability to resolve rainfall adequately in time and space for urban hydrological applications depends on the velocity of rainfall fields. By studies of variograms at different temporal aggregation levels and analysing runoff responses, Ochoa-Rodriguez et al. (2015) found a strong interaction between the temporal and spatial resolutions and the impacts on urban runoff response. Berne et al. (2004) suggested a relation between the temporal $(t$ in min) and spatial $(r$ in $\mathrm{km})$ resolution of $r=1.5 t^{0.5}$ for Mediterranean rainfall conditions, and van de Beek et al. (2012) extrapolated this to $r=5 t^{0.3}$ for summer conditions in the Netherlands.

The type and severity of a storm might also set requirements to the space-time resolution. A high-intensity convective thunderstorm with small spatial extent will need a higher resolution in both space and time to be resolved, in contrast to a stratiform long-duration storm. This is again related to the runoff response of the system in question. Germann and Joss (2001), Berne et al. (2004), Bruni et al. (2015), and Ochoa-Rodriguez et al. (2015) suggested applying climatological variograms to characterize the spatial structure of rainfall fields and investigating the spatial resolution requirements (given a specific temporal resolution) in order to resolve the spatial structure of rainfall fields in a sufficient way for urban hydrological applications.

\subsubsection{Rainfall estimation, radar data adjustment, and quality}

The use of radar data implies that the data are of good quality. There are numerous items such as radar hardware calibration, clutter removal, and overshooting/vertical profile correction (Michelson et al., 2005; Villarini and Krajewski, 2010) which may play a role before radar reflectivity data can be converted into reliable rainfall intensities. A thorough quality check and potential correction are therefore required. Disturbances for a good radar measurement may be undesired reflections off mountains or high towers, airplanes, ships, wind turbines, attenuation by heavy rain or hail, snow or melting snow instead of rainfall, anomalous propagation conditions, and others. Methods to test for these problems exist, and they are partly reduced by dual-polarization information from newgeneration radars. The preprocessing of radar data by meteorological services usually only covers a part of the above points.

Observed radar reflectivity can be converted into rain rates (intensities), but in order to produce valid quantitative precipitation estimates (QPEs), comparison and adjustment against ground observations are required. This is most often referred to as radar rainfall adjustment or radar-rain gauge merging and is presented in the following section. 
Rain gauges for adjustment also need to be of high quality. Frequently observed shortcomings of rain gauge data are missing data, time shifts (or differently set clocks), clogging of the gauge, data transmission dropouts, gauge calibration errors, local wind effects around gauges leading to measurement errors, or gauge sampling errors (e.g. Ciach, 2003; Villarini et al., 2008b; Gires et al., 2014b). In order to avoid random or systematic errors, such effects need to be eliminated before rain gauge data are used to adjust radar rainfall.

\subsubsection{Reflectivity-rain rate conversion}

Radar reflectivity, $Z\left(\mathrm{~mm}^{6} \mathrm{~m}^{-3}\right)$, depends on the drop size distribution (DSD) of the target precipitation. Conversion into rain rate, $R\left(\mathrm{~mm} \mathrm{~h}^{-1}\right)$, therefore depends on the size of the individual drops. As documented by numerous authors (e.g. Marshall and Palmer, 1945; Uijlenhoet, 2001) the most typical conversion for single-polarization radars is to apply a two-parameter power-law relationship to describe the relation between rain rate and reflectivity $(Z-R$ relationship): $Z=a R^{b}$. Since the power-law parameters will vary with the $D S D$ shape, i.e. the type of rain, they will not be constant in time. One solution is to adjust the $Z-R$ relationship continuously by use of ground observations. It is however more common to apply a fixed $Z-R$ relationship and perform a posteriori bias adjustment (see next section). Whereas traditional $Z-R$ conversion has been documented in numerous applications of radar, there are recent advances in the application of dual-polarized radars which enable accurate QPE assessment using polarimetric parameters (e.g. Scarchilli et al., 1993; Bringi and Chandrasekar, 2001; Anagnostou et al., 2004; Anagnostou and Anagnostou, 2008; Bringi et al., 2011; Mishra et al., 2016). Polarization of a radar signal characterizes the orientation of the electric field (both transmitted and received). Dual-polarimetric radars transmit a radar signal alternately in horizontal $(\mathrm{H})$ and vertical $(\mathrm{V})$ polarization. Depending on the shape of the raindrops, two different signals will be received: reflectivities $Z_{\mathrm{HH}}$ and $Z_{\mathrm{VV}}$. Additionally, the phases of the horizontally and vertically polarized return signals, $f_{\mathrm{HH}}$ and $f_{\mathrm{VV}}$, are measured (Illingworth, 2004). Four parameters can be defined based on the polarimetric measurements: differential reflectivity $Z_{\mathrm{dr}}$, linear depolarization ratio $L_{\mathrm{dr}}$, co-polar correlation coefficient $r_{\mathrm{co}}$ and the specific differential phase $K_{\mathrm{dp}}$ (Illingworth, 2004). It has been shown that $K_{\mathrm{dp}}$ is proportional to the product of rainwater content and the mass-weighted mean diameter (Bringi and Chandrasekar, 2001) and thus can be used to estimate rainfall rates. The advantage of using $K_{\mathrm{dp}}$ for rainfall rate estimation is that it is more sensitive to the raindrop shape, and thus rainfall rate can be estimated from $K_{\mathrm{dp}}$ in the case of rain-hail mixture. As soon as the hydrometeors are spherical or quasi-spherical, $K_{\mathrm{dp}}$ is about $0^{\circ} \mathrm{km}^{-1}$ (hail, light rain). The advantage of using $K_{\mathrm{dp}}$ is also that it is independent of radar calibration and not sensitive to attenuation, an issue of particular importance at X-band frequency. $K_{\mathrm{dp}}$ can only be estimated for medium to high rainfall rates (Otto and Russchenberg, 2011).

\subsubsection{Bias adjustment against ground observations}

Many different methods have emerged in the last decade for adjusting rain rates estimated from reflectivities, and several profound review papers on different adjustment/merging techniques related to hydrological applications exist (e.g. Goudenhoofdt and Delobbe, 2009; Wang et al., 2013; McKee and Binns, 2016). For specific details we refer to these. Below, we present some of the most widely applied methods.

One of the simplest methods of adjusting radar rainfall data has been proposed by Smith and Krajewski (1991), who introduced the concept of mean field bias (MFB) adjustment. The concept is to estimate the ratio between accumulated rainfall in a number of ground observation points (rain gauges) and accumulated radar rainfall in the corresponding points (or grid cells if the radar data are projected onto a Cartesian grid). Under the assumption that the radar field has a homogeneous DSD and that no systematic range effects in the radar rainfall retrievals are present, the whole radar field is multiplied by the MFB factor. The MFB factor should be based on a temporal integration of data over a period of time in which the DSD does not change significantly. If the integration period is too short (e.g. in the range of the temporal resolution of radar data), the bias assessment becomes vulnerable to random errors. On the other hand, if the integration period is too long, the adjusted radar rainfall might be inaccurate due to temporal changes in the DSD (Krajewski and Smith, 2002). Within urban hydrology most commonly hourly (e.g. Borga et al., 2002; Thorndahl et al., 2014b; RicoRamirez et al., 2015; Wang et al., 2015b) or daily (e.g. Seo and Breidenbach, 2002; Wright et al., 2012; Thorndahl et al., 2014a) MFB adjustment is applied.

The optimal temporal integration period or spatial aggregation level is to a large extent dependent on the representativeness of the gauges (gauge network density) to capture the temporal and spatial variability of the rain (e.g. Gires et al., 2014a). It is difficult to recommend specific gauge network densities for radar rainfall adjustment since the optimal value will depend on storm type, homogeneity of the rain gauge network, orographic features of the rain, adjustment methods, etc. Generally you will need a rain gauge network with a higher density for smaller aggregation levels or, in other words, the density of the rain gauge network will determine the temporal aggregation level of the radar rain gauge adjustment. McKee and Binns (2016) suggest conducting a sensitivity analysis in order to identify the effect of gauge density on rainfall estimation.

For annual precipitation measurements the WMO (2008) recommends 1 per $5750 \mathrm{~km}^{2}$ for plains and 1 per $2500 \mathrm{~km}^{2}$ for mountainous areas. Furthermore, for application in design and management of stormwater systems the WMO (2008) recommends 1 rain gauge per $10-20 \mathrm{~km}^{2}$ for 
urban areas. For radar rainfall adjustment such density is not necessary since the radar data will provide information on the spatial and temporal variability of the rainfall. As an example Goudenhoofdt and Delobbe (2016) found no remarkable improvement in the MFB assessment of daily rainfall for gauge densities between 1 per 500 and 1 per $135 \mathrm{~km}^{2}$. Wright et al. (2014b) also examined the role of gauge density in MFB estimation, concluding that 1 gauge per $100 \mathrm{~km}^{2}$ provided a robust bias adjustment on a daily scale.

MFB adjustment has an implicit range adjustment feature, in that, at least for storms that do not cover a large portion of the radar coverage, the gauges reporting positive rain will be within a close distance to each other and at a similar distance from the radar, and thus the computed MFB will in some sense compensate for range dependent bias.

As an extension of the MFB adjustment, the concept of conditional MFB adjustment was proposed by Ciach et al. (2000, 2007) and Villarini et al. (2008a). The conditional MFB adjustment introduces a range (distance) dependent bias in order to account for rain rate dependent biases, especially for convective rainfall with rapidly changing DSD. Wright et al. (2014b) demonstrate that especially estimation of large rain rates can be improved significantly by introducing conditional MFB adjustment, whereas Thorndahl et al. (2014b) conclude an insignificant effect of conditional MFB adjustment for advection interpolated radar data.

Spatial variability adjustment approaches and geostatistical merging of radar and rain gauge data are developed to account for range dependence issues as well as heterogeneous DSDs. They represent another range of methods which are widely applied for QPEs. The concept here is to merge the spatial variability of the radar rainfall fields into the interpolated rain gauge precipitation fields in order to increase the spatial resolution of this product. The interpolation can be performed by many different spatial interpolation methods, e.g. variations of Kriging (Krajewski, 1987; Todini, 2001; Sinclair and Pegram, 2005; Haberlandt, 2007; Goudenhoofdt and Delobbe, 2009; Velasco-Forero et al., 2009; He et al., 2011; Berndt et al., 2014; Rabiei and Haberlandt, 2015), or by inverse distance weighting or Thiessen polygon weighting (Johnson et al., 1999; Haberlandt, 2007). The Krigingbased methods rely on variograms for describing the spatial dependence in rainfall fields and are in general more computationally demanding than weighting methods. The latter are therefore often used in real-time operation.

Other methods such as the singularity approach (Wang et al., 2015b) have been proposed in order to overcome problems with spatial smoothing as a result of the variograms in the Kriging-based methods. Geostatistical merging and spatially distributed bias adjustment is mostly applied for radar composites or in mountainous areas with orographic rainfall effects (e.g. Germann et al., 2006; Sideris et al., 2014). Merged rainfall products are described in Sect 2.2.3.

Another alternative to the optimization and sensitivity approaches of the radar gauge adjustment described above is to model errors and thereby acknowledge uncertainties in rainfall estimates (e.g. Ciach et al., 2007; Gires et al., 2012; Pegram et al., 2011; Villarini et al., 2014; Rico-Ramirez et al., 2015). It is expected that these uncertainty-based methods and development of rainfall ensembles for hydrological applications will gain more impact in future applications, concurrently with development in probabilistic/ensemble models for urban hydrology.

\subsubsection{Operational radar rainfall products}

Today, most national meteorological services produce radar rainfall products consisting of radar composites from national radar networks. They provide state of the art corrected CAPPI or PPI products which have been adjusted or merged with rain gauge network data in order to provide users with the best possible rainfall estimates for historical records or in real time. The majority of operational products are based on rather simple range and MFB approaches as described in Sect. 2.2.2 (e.g. Gjertsen et al., 2004). Examples of products are, in Germany, RADOLAN, in the UK, NIMROD, and in the USA, NEXRAD.

These QPE products are often provided in a fixed Cartesian grid with data summarized over a fixed time period. In some cases only historical data in hourly or daily precipitation maps but in other cases also fine temporal resolution data are available.

Generating radar composites merging data from two or more radars might be subject to inconsistencies in radar data due to merging of data from different elevations, with different scanning strategies, and using different merging techniques. In application of commercial QPE products, it is important to be aware of these inconsistencies.

\subsubsection{Dynamic adjustment in real time}

Operational real-time continuous adjustment of radar rainfall against rain gauges constitutes a challenge in comparison to event-based or discontinuous adjustment based on historical data (offline mode). Nonetheless, for real-time operation of urban hydrological systems, it is crucial to be able to produce valid rainfall estimates in an online mode. The real-time adjustment is especially difficult in the beginning of rainfall events with no prior rain gauge data recordings or in situations with large spatial rainfall variability. In these cases where rain gauge observations might be sparse and thus subject to domain sampling errors, bias adjustment might be dominated by random factors and can easily result in a erroneous adjustment (Seo et al., 1999; Krajewski and Smith, 2002; Nielsen et al., 2014a). The accuracy of a real-time bias adjustment is thus dependent on the temporal aggregation scale at which the adjustment is performed. The shorter the aggregation scale (e.g. hourly or sub-hourly) the larger the risk of erroneous adjustment due to sampling errors and the larger the aggregation scale (e.g. daily or super-daily) the 
larger the risk of errors due to changes in DSD and bias over the aggregation interval. Several authors apply MFB adjustment rather than area-based adjustment in real-time operation due to the fact that the latter is more vulnerable to rain gauge sampling errors (Seo et al., 1999; Borga et al., 2000). In order to avoid abrupt changes in bias several authors have suggested applying algorithms to smooth the bias in time, e.g. using Kalman filtering (Chumchean et al., 2006) or exponential smoothing (Seo and Breidenbach, 2002).

\subsubsection{Choosing adjustment procedures for hydrological modelling}

It is evident that for hydrological modelling, accurate rainfall estimates at ground level are desired. Different adjustment methods and their impacts have been investigated in recent studies, e.g. Quirmbach and Schultz (2002), Tilford et al. (2002), Vieux and Bedient (2004a), Emmanuel et al. (2012a), Gires et al. (2012), Goormans and Willems (2013), Wang et al. (2013), Leonhardt et al. (2014), and Rico-Ramirez et al. (2015). It is difficult to recommend one method of adjustment over another, since it to a large extent depends on the application considered. Instead we have identified some of the key issues related to the requirements of radar rainfall adjustment or radar-rain gauge merging for runoff response modelling in urban areas.

1. Catchment characteristics are important for the choice of the radar rainfall adjustment method.

The choice of the adjustment method depends on the required accuracy of the spatially distributed rainfall in the application and the radar rainfall product available. For catchments and spatially homogeneous rainfall events, an adjustment using rain gauges inside or outside the catchment and a fixed MFB adjustment might be sufficient to represent rainfall variability. For a large catchment potentially covered by multiple radars, geostatistical merging techniques are required to represent the variability in DSD within the study domain, and thus more sophisticated techniques might be preferred (see e.g. Wang et al., 2013, 2015b).

2. Overall model uncertainty might have a significant impact on the urban hydrological model outputs, leaving accurate radar rainfall adjustment less crucial.

Urban hydrological model outputs are subject to uncertainties associated with rainfall inputs as well as representation of hydrological and hydraulic processes, expressed in parameter and model structure uncertainties (e.g. Freni et al., 2008; Thorndahl and Willems, 2008; Thorndahl et al., 2008; Willems, 2008; Dotto et al., 2012). In cases where parameter uncertainty estimation of such processes dominates runoff response, the rainfall input to urban hydrological models may become less important. Instead of adjusting the radar rainfall in- dividually, some authors have therefore calibrated or optimized hydrological models directly to match runoff response observations without specific adjustment of the rainfall input (Krämer et al., 2005; Ahm et al., 2013; Thorndahl and Rasmussen, 2013; Löwe et al., 2014). However, this is recommended only if parameter or model uncertainties are high and/or radar rainfall data adjustment is not possible, because it may lead to error compensation with undesired consequences for prediction.

3. In real-time applications, change in storm characteristics might influence the radar rainfall inputs to hydrological models.

It is of utmost importance that real-time adjustment of radar data reflects the potential changes in DSD. In the case of rapid changes e.g. between convective and stratiform precipitation, a bias shift might occur. The aggregation time on which a bias (either mean field of spatially varying) adjustment is performed should therefore be able to reflect these changes. This will to a large degree also depend on the density of rain gauges available for adjustment. Required gauge density for an unambiguous adjustment will thus depend on the aggregation level on which the adjustment is performed as well as the storm extent and homogeneity of the storm.

\subsection{Nowcasting of radar rainfall}

Next to the interpolation for urban design, control or scenario simulation applications, temporal extrapolation of radar rainfall fields forms the basis of real-time forecasting and control (e.g. Austin and Bellon, 1974; Einfalt et al., 1990; Sharif et al., 2006; Smith et al., 2007; Javier et al., 2007; Achleitner et al., 2009; Einfalt et al., 2009; Liguori et al., 2012; Schellart et al., 2012a; Wang et al., 2012; Thorndahl et al., 2013; Ntegeka et al., 2015). Due to the short response time of the urban drainage system and the short lifetime and small spatial size of convective rain cells, urban rainfall forecasts are only reliable for very short lead times (Achleitner et al., 2009; Foresti et al., 2016). Short-term forecasts are called nowcasts and provide input for real-time warning and/or control of urban floods or CSO pollution.

Several generic methods have been developed to nowcast radar data, based on deterministic approaches, e.g. TREC (Rinehart and Garvey, 1978), CO-TREC (Li et al., 1995), SCIT (Johnson et al., 1998; Mecklenburg et al., 2000), and SCOUT (Einfalt et al., 1990), or stochastic approaches, e.g. MAPLE (Turner et al., 2004), SBMcast (Berenguer et al., 2005, 2011), and STEPS (Bowler et al., 2006). We refer to the individual papers for detailed descriptions of the methods and focus instead on the application of nowcasts within urban hydrological applications here. We have identified three issues which constitute the current major challenges. 
1. Extrapolation of observed radar rainfall has a limited lead time.

Despite development of the aforementioned methods, rainfall nowcasting for urban drainage applications is still in its infancy. Although rain cells can be extrapolated by radar image extrapolation (e.g. Thorndahl et al., 2013; Löwe et al., 2014) or by applying cell tracking (e.g. Sharif et al., 2006; Einfalt et al., 2009; Muñoz et al., 2015), this is often of limited value given the limited duration of rain cells, especially during convective conditions. The quality of an extrapolation-based nowcast depends on the radar range, possible merging of radar networks, resolution, climate zone, and rainfall type. For a standard deterministic nowcast, the lead time varies between less than $30 \mathrm{~min}$ (small convective cells) and more than $2 \mathrm{~h}$ (large-scale slow moving systems). As a rule of thumb, extrapolation is more difficult with small rainfall cells and for small target areas, and less difficult with large rain fields and large target areas.

\section{For reliable nowcasting, stochastic uncertainty should} be included.

The most promising alternative to simple extrapolation of radar rainfall data is to perturb the deterministic radar extrapolation with stochastic noise to account for the unpredictable rainfall growth and decay processes (Bowler et al., 2006; Germann et al., 2009; Liguori and Rico-Ramirez, 2013). The stochastic noise model aims to describe the nowcast error together with its spatial and temporal correlations. In the Short-Term Ensemble Prediction System (STEPS), this is done by adding stochastic perturbations to the deterministic Lagrangian extrapolation of radar images (Liguori and Rico-Ramirez, 2013). The perturbations moreover aim to reproduce the dynamic scaling of precipitation fields, i.e. the observation that large-scale rainfall structures are more persistent and predictable than small-scale convective cells. STEPS was originally co-developed by the UK Met Office and the Australian Bureau of Meteorology, and is currently further customized for urban applications, e.g. in the UK (Liguori et al., 2012; Liguori and Rico-Ramirez, 2012), STEPS-BE for the Belgian version (Foresti et al., 2016). It provides probabilistic ensemble nowcasts. So far, however, these nowcasting systems have relied on radar data that are too coarse for urban applications (e.g. $1 \mathrm{~km}$ resolution C-band radar data for STEPS-BE).

\section{There is a challenge in combining high resolution radar} observations with nowcasts.

Future developments will likely involve the use of higher resolution X-band radar data. These are currently only available at experimental sites (e.g. http: //www.casa.umass.edu/) without large spatial coverage and with short ranges that hamper extrapolation. A future research challenge will be to combine the coarser resolution radar data, which are available at large scale, with the higher resolution but more local rainfall estimates (Nielsen et al., 2014c). The coarser but largerscale radar data allow estimation of velocity fields and the advection of radar composites, whereas the local, higher resolution estimates allow near-real-time spatial interpolation and dynamic calibration of the stochastic noise model parameters. Additional blending or assimilation with numerical weather prediction models increases the lead time (Liguori and Rico-Ramirez, 2012, 2013; Jensen et al., 2015; Korsholm et al., 2015).

\section{The value of radar rainfall for urban hydrology}

The field of urban hydrology has over the last decade expanded the focus from analysis, design, and operation of urban stormwater systems and wastewater treatment plants. Today, the key drivers of research include urban city resilience to hydrological extremes, water and resource recovery, climate change impacts and adaption, as well as integration with other city planning and management disciplines, including urban development. This has led to a need for new and more diverse precipitation inputs, both to address the challenges mentioned above and also because urban hydrology is becoming more complex with implementation of sustainable stormwater management infrastructure. This increased complexity often implies that the spatial distribution of precipitation becomes even more important in both planning and operation of urban systems, and therefore urban hydrology will require better resolved rainfall products in the future. The current main application fields for radar rainfall in urban hydrology are shown in Table 3. As shown in the table, several new application fields have emerged over the last decade. Radar measurements can provide important contributions to these new fields. The improvements discussed in the previous section have also enhanced the possibility of using radar data in the existing application fields.

\subsection{General statistical and hydrometeorological characterization of precipitation at urban scales}

Long-term analysis of precipitation using single or multiple rain gauges has been applied for several decades. They provide valuable information to decision-making within design and analysis of urban water infrastructure, both for quantifying uncertainty and for studying non-stationary behaviour (e.g. Ntegeka and Willems, 2008; Madsen et al., 2009; Willems, 2013a, b; Gregersen et al., 2014). When using single site rain gauges for large catchments, simple areal reduction factors (ARFs) can be applied to account for the spatial distribution of extremes (e.g. Sivapalan and Blöschl, 1998; Vaes et al., 2005; and Wright et al., 2014a). While 
Table 3. Application fields for radar rainfall in urban hydrology. Applications that have emerged significantly since Einfalt et al. (2004) are marked with bold. Numbers in parentheses indicate which sub-section discusses the particular application.

\begin{tabular}{|c|c|}
\hline Offline applications & Online applications \\
\hline $\begin{array}{l}\text { - General statistical and hydrometeorological characterization of } \\
\text { precipitation at urban scale (Sect. 3.1) }\end{array}$ & - Nowcasting and operational warning (Sect. 3.4) \\
\hline - Present climate & - Severe rainfall warning \\
\hline - Extremes & - Flow/flood warning based on online hydrological mod- \\
\hline - Future climate & \\
\hline - Re-analysis of damaging extreme events (Sect. 3.2) & $\begin{array}{l}\text { - Operational real-time control of hydrological systems } \\
\text { (Sect. 3.5) }\end{array}$ \\
\hline - Insurance claims & - Nowcasting \\
\hline - Hydrological re-analysis of flood events & - Real-time hydrological models with data assimilation \\
\hline $\begin{array}{l}\text { - Distributed hydrological modelling for flood risk assess- } \\
\text { ment }\end{array}$ & $\begin{array}{l}\text { - Scenario/ensemble modelling for online evaluation of } \\
\text { control strategies }\end{array}$ \\
\hline \multicolumn{2}{|l|}{ - Urban water management (Sect. 3.3) } \\
\hline \multicolumn{2}{|l|}{ - Design of basins and pipes } \\
\hline - Resilience and livability measures & \\
\hline
\end{tabular}

this is sufficient within a given catchment, it is not adequate to validate spatial rainfall as modelled by regional climate models (RCMs) when describing anticipated future climatic changes over a range of scales. Rather, this verification should be based on spatial datasets using historical data with the same spatial resolution as the RCMs in order to test the model performance on the current climate as a measure of its accuracy in predicting future changes. These datasets are typically still based on point measurements, but there are known shortcomings of this approach, especially in areas with low density of measurement stations (e.g. Haylock et al., 2008; Lenderink, 2010). Radar rainfall data are expected to be able to provide better estimates of precipitation for these gridded datasets. An example of such an application is Kendon et al. (2014), where a high resolution model $(1.5 \times 1.5 \mathrm{~km}$ grid size) covering part of the UK is validated against a 9-year series of radar rainfall data, because a suitable gridded dataset cannot be constructed based on point measurements. Similar datasets are being constructed for other regions (Overeem et al., 2009a; Thorndahl et al., 2014b; Wright et al., 2014c; Berg et al., 2015; Goudenhoofdt and Delobbe, 2016). Climate change models with this high resolution can provide a much better physical description of the climatic changes of sub-daily extreme precipitation at high spatial resolution (Tabari et al., 2016), and hence such uses are clearly an emerging field for radar applications in urban hydrology.
As radar data quality improves, it can also be directly used to estimate precipitation extremes, for example in the form of traditional intensity-duration-frequency curves (e.g. Overeem et al., 2009b, 2010; Marra and Morin, 2015; Paixao et al., 2015). For small-scale urban applications this requires an understanding of the spatial rainfall variability at the radar subpixel scale. Recent advances in stochastic space-time rainfall modelling allow the quantification of this subpixel variability explicitly and the generation of ensembles of IDF curves at radar subpixel scale which remove the bias in radar IDF curves (Peleg et al., 2016b). This can be of major importance for very local estimates of rainfall extremes from radar data.

\subsection{Re-analysis of damaging extreme events}

Re-analysis of extreme events was mentioned in Einfalt et al. (2004) as an important field of application of radar rainfall and a field where good approaches had been developed. The continued development of radars has enabled very accurate re-analyses of historical events (Jessen et al., 2005; Smith et al., 2013; Yang et al., 2013; Thorndahl et al., 2014a, b; Wright et al., 2014a, b).

The field of distributed 1-D-2-D hydraulic/hydrological models for urban flood simulations has matured and standard methods have been developed (e.g. Zhou et al., 2012; Henonin et al., 2013). The state of the art described in these 
papers use point rainfall statistics as opposed to spatial rainfall inputs. Since there is large uncertainty in estimating volume estimates for high return periods, it is argued that the error not including spatial variability of rainfall within the catchment is minor.

However, recent studies have also partitioned the contribution of spatial and temporal variability in rainfall to urban flow quantiles, and shown that spatial rainfall variability does matter, especially for high return periods (e.g. Peleg et al., 2016a).

\subsection{Urban water management}

The paradigm of using point rainfall data from rain gauges at very high temporal resolution, assuming them to be representative of an entire urban catchment, is challenged by several factors. First, rainfall data from high resolution radar have shown high spatial variability at the intra-urban scale. Moreover, many cities experience substantial development in the form of urban sprawl. This leads to very large cities, where uniform precipitation cannot be assumed, because the catchment size is larger than the spatial representativeness of point precipitation. Hence, there is a far more complex hydrological response from large urban and peri-urban areas compared to smaller urban areas.

Another driver is the climate change adaptation needs of larger cities. Many countries and regions explicitly mention nature-based solutions or sustainable urban drainage systems as a very important component in this adaptation, including countries and regions such as China, the EU, and Australia. These wetlands, rain gardens, soakaways etc. are making the hydrological response of cities more complex. Hence, there is a need to generate spatially distributed rainfall series at high resolution in space and time. As mentioned in Sect. 3.1, such series are becoming available in a few places based on radar measurements. Means to develop artificial series based on stochastic properties are being investigated (e.g. Raut et al., 2012; Sørup et al., 2016), but there is a long way to go before standard procedures are identified. Over time, these procedures will most certainly be based on spatially distributed rainfall observations such as radar rainfall observations.

\subsection{Nowcasting and operational warning}

With a higher risk of damage due to heavy rainfall in urban areas as a consequence of climate change and increased urbanization, there is a motivation to develop reliable warning systems which have a higher level of detail regarding urban hydrology than traditional numerical weather prediction model forecasts of heavy rainfall, cloud bursts, hurricanes, etc. The evolution in computational power and models enables operational weather models to provide finer resolutions than just a few years ago. However, neither temporal resolution nor spatial resolution is currently fine enough to resolve rainfall sufficiently for many urban hydrological ap- plications (e.g. Thorndahl et al., 2016). Furthermore, numerical weather prediction models may still have offsets of tens of kilometers in terms of predicting the exact location of a rain cell. This constitutes a significant problem in applying weather model data for urban hydrological systems, where the location of heavy rainfall is key. For short lead times this problem can to some extent be solved by assimilating radar nowcasts into numerical weather prediction models in order to improve initial conditions of the latter (e.g. Stephan et al., 2008; Dixon et al., 2009; Jensen et al., 2015). Operational systems with assimilation of radar data are rare, so in order to issue valid urban hydrological warnings, it can be beneficial to have (1) online rainfall estimates at high temporal and spatial resolution from radars and potentially also nowcasted data, as well as (2) online information on the current state of the hydrological system, e.g. baseflow, soil saturation, and residual storage capacity.

Examples of operational warning systems based on radar data are local flood warning systems, systems for emergency planning in case of flooding, warning systems for capacity of receiving waters, etc. Operational warning systems based on radar observations have potential in rainfall warnings if radar rainfall estimates exceed a specified threshold (e.g. Einfalt and Luers, 2015) or as hydrological warnings where radar observations (or nowcasts of radar data) are applied as input to an online hydrological model as described above. With regards to the latter there are still rather few applications of operational online distributed 2-D or 1-D-2-D flood warning models, since they tend to be too computationally expensive to run in real time. Instead simplified lumped models or 1-D models are often applied (Bell and Moore, 1998; Sharif et al., 2006; Javier et al., 2007; Smith et al., 2007; Fang et al., 2008; Einfalt et al., 2009; Duncan et al., 2013; Wolfs and Willems, 2017).

In the literature, there are various examples of realtime operation of urban drainage models, which are applied to warn if flow, water level, CSO volume, storage filling, etc., exceed certain thresholds, e.g. Yuan et al. (1999), Vieux and Bedient (2004a, b), Vieux et al. (2008), Achleitner et al. (2009), Liguori et al. (2012), Liguori and RicoRamirez (2012), Schellart et al. (2012a), Dirckx (2013), Thorndahl et al. (2013), Thorndahl and Rasmussen (2013), Löwe et al. (2014), Schellart et al. (2014), and Löwe et al. (2016). Several of these are pre-operational and have studied the potentials of applying radar data (with or without nowcasting) in real-time prediction of sewer system states.

Simulation of the probabilistic urban rainfall nowcasts in urban drainage models allows probabilistic nowcasts to be obtained of the inundation hazards and risks in urban areas. Ntegeka et al. (2015) have shown how probabilistic urban inundation risk maps can be obtained by combining STEPSbased rainfall nowcasts with a nested 1-D-2-D sewer hydraulic and surface inundation model, and a model to assess the damages and social consequences of the urban inundations (Van Ootegem et al., 2017). Such a system, however, 
only becomes useful for operational management when the uncertainties in the inundation risks can be communicated in a compact and clear way, and when these are informative and manageable by decision makers or the wider public.

An example of a runoff forecasting system is provided in Fig. 3. The figure illustrates differences between runoff simulation with radar observations, a deterministic radar nowcast as well as a probabilistic nowcast with 300 ensemble members for forecast lead times of 10, 30, and $60 \mathrm{~min}$.

\subsection{Operational real-time control}

Model-based real-time control of urban drainage systems has evolved significantly during the past decade. Many modelbased real-time control methods were developed for applications with online in-sewer instrumentation or rain gauges for local systems (e.g. Schütze et al., 2004). With advances in estimating spatially distributed rainfall with radars, it is possible to implement real-time control on a much larger scale, e.g. a whole city. By exploiting the spatial variability of rain and successive unequal local loading of the hydrological systems, novel developed methods aim at utilizing spare capacity systems in order to reduce spills, overflows, flooding, etc. (e.g. Faure and Auchet, 1999; Pfister and Cassar, 1999; Mounce et al., 2014).

Other real-time control applications have been used to estimate the loads on waste water treatment plants in order to reduce spills of untreated waste and stormwater and to optimize treatment processes during rain (Quirmbach and Schultz, 1999; Fuchs and Beeneken, 2005; Thorndahl et al., 2013; Vezzaro and Grum, 2014; Kroll et al., 2016). With large linked hydrological systems, centralization of treatment plants in urban areas, advances in model predictions and data, there seems to be a large potential for global predictive control of hydrological systems in cities, which is not yet fully exploited.

\section{Summary and recommendations}

This paper summarized literature findings from the last decade in three key research areas: temporal and spatial radar rainfall resolution in relation to their use in urban hydrology, radar rainfall data adjustment and quality, and use of radar data for rainfall nowcasting and online applications.

In the following, we summarize emerging developments and applications of radar rainfall in urban hydrology that were identified in this review and provide recommendations for future research as well as practical recommendations for the application of radar rainfall in urban hydrology.

\section{Radar resolution}

A recent and promising development is the installation of X-band polarimetric radars in urban areas, providing high resolution rainfall estimates, typically at or be- low $1 \mathrm{~min}$ and $100 \mathrm{~m}$, but with a shorter range than $\mathrm{C}$ and $\mathrm{S}$-band radars. While $\mathrm{X}$-band radar is sensitive to attenuation due to its frequency band, the use of polarimetric signals provides additional parameters insensitive to attenuation, thus solving an important problem associated with X-band radars. While dual-polarimetric radars are capable of providing an independent rainfall product, single-polarimetric X-band radars on the other hand require extensive post-processing incorporating data from additional sensors to obtain reliable, high resolution rainfall estimates. In S- and C-band radar networks, high resolution products are starting to be developed, based on for instance compressed pulse lengths. This reveals a transition from use of primarily research radars with high resolution to more operational products from meteorological services focusing also on high resolution for urban hydrological application.

Where high resolution radar rainfall products are not available, spatial and temporal downscaling (advection interpolation) is applied to obtain higher resolution rainfall estimates, starting from coarse resolution radar products. Downscaling can be based on physical processes or on stochastic principles, the latter being more flexible for including uncertainty and being less computationally intensive, but also having more difficulty in reproducing the natural, physical structure of storms.

\section{Radar data adjustment and rainfall data quality}

Radar rainfall estimates suffer from uncertainties associated with variability in drop size distribution, partial beam filling, overshooting, and signal attenuation. One way to reduce these uncertainties is by using polarimetric signals, another way is by reducing distance to the radar, by increasing the density of the radar network. Both require significant investments and in many situations are not foreseen in the near future. This implies that radar data adjustment based on a network of rain gauges will still be required to reduce radar rainfall uncertainty. The quality of radar data adjustment in turn depends on the density and quality of the rain gauge network. The optimal temporal integration period or spatial aggregation level for radar adjustment is directly related to the ability of the rain gauge network to capture the temporal and spatial rainfall variability. It is difficult to recommend specific gauge network densities for radar rainfall adjustment since the optimal value will depend on storm type, homogeneity of the rain gauge network, orographic features, adjustment methods, etc. as well as the specifications of the urban hydrological application. In many studies simple mean field bias adjustment between radar and rain gauges has proven sufficient and robust which is probably also the reason that this method is applied in many operational systems. At present, the more advanced geostatistical approaches to 

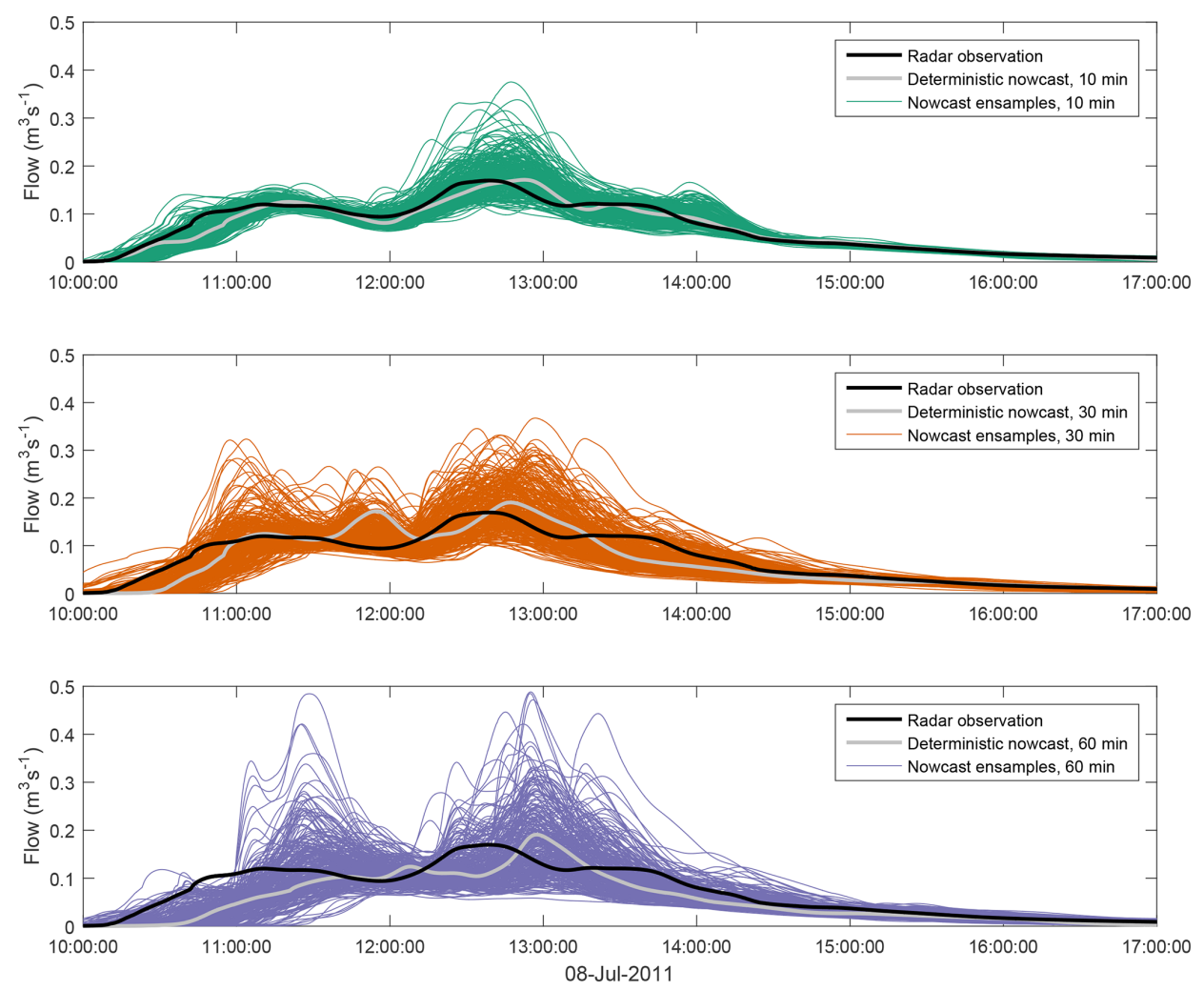

Figure 3. Examples of runoff forecast prediction in an urban drainage system in Frejlev, Denmark, using a radar ensemble nowcast algorithm (Jensen et al., 2017). An ensemble of 300 nowcasts, a deterministic nowcast, and observed radar data are applied as inputs to an urban drainage model (Thorndahl et al., 2006; Thorndahl and Rasmussen, 2013) covering an area of $0.8 \mathrm{~km}^{2}$ with an impervious area of approx. $40 \%$. Six radar pixels with a $2 \times 2 \mathrm{~km}^{2}$ resolution cover the area. The radar is operated by the Danish Meteorological Institute. Maximum observed rainfall intensities are $6 \mathrm{~mm} \mathrm{~h}^{-1}$ and the observed accumulated rainfall is $11.2 \mathrm{~mm}$. It is evident that there is a significant increase in the ensemble spread as a function of the different shown forecast lead times of 10, 30, and 60 min, respectively.

bias adjustment are mostly applied within the research community.

\section{Nowcasting of rainfall and online applications}

Whereas numerical weather forecast models have too coarse a spatial and temporal resolution for reliable forecasts in urban hydrological applications, the use of short-term forecasting (nowcasting) of radar rainfall shows potential in many online urban hydrological applications with warning systems or real-time control of urban hydrological systems. Currently, there are some drawbacks with pure radar extrapolation methods in terms of predicting convective rainfall with rapidly evolving storm structure evolution. In order to overcome these problems, stochastic blending of radar rainfall observations/extrapolations with numerical weather prediction models ensembles shows potential for fast hydrological response systems. Given the high nowcasting uncertainties, the explicit consideration of these uncertainties, e.g. by means of stochastic modelling approaches, is important.
Pluvial flood warning for small urban catchments based on critical rainfall thresholds or pluvial flood warning based on real-time urban hydrological modelling are expected to be developed significantly in forthcoming years in order to adapt to climate changes and increased urbanization.

For urban hydrological applications in general, higher resolution and higher accuracy rainfall estimates are beneficial for a better understanding of the hydrological response. Higher accuracy comes with required investments in equipment (X-band radar, polarimetric capability or dense rain gauge networks for adjustment) that need to be justifiable from either a research or societal perspective (higher efficiency of operational control, more accurate early warning). Some general recommendations can be derived from the recent literature as to requirements for radar rainfall resolution: studies have shown that the sensitivity of the hydrological response and thus the added value of higher resolution rainfall data input increases for smaller catchment size, larger catchment spatial variability, smaller storm size, larger storm variability, and higher storm movement velocity. An impor- 
tant consideration here is that the accuracy of rainfall estimates generally decreases for higher resolution: the accuracy of storm total rainfall is typically much higher than for 515 min rainfall estimates; the same applies for spatial aggregation levels. Conversely, higher rainfall measurement resolution results in higher accuracy of rainfall estimates than if rainfall estimates are derived from coarse resolutions. In applications, a balance will always be needed between the benefit of higher accuracy and the required investment obtaining such accuracy. In a nowcasting and near-real-time context, challenges are even higher, because data correction and adjustment windows are typically short, while false early warnings can have large societal impacts.

Whereas the initial word of the title of the Einfalt et al. (2004) paper ("Towards a roadmap for use of radar rainfall data in urban drainage") suggested a progression, this paper has demonstrated that radar rainfall data presently are applied in many operational systems and that radar has become an invaluable source of data along with other types of observations applied in urban hydrology. That said, there is still research to be conducted in order to improve radar rainfall estimates, e.g. especially with regards to dual polarimetry, uncertainty assessment and generation of realistic ensemble forecasts, combined radar and weather model rainfall products, and real-time applications.

Author contributions. S. Thorndahl coordinated the joint collaboration and developed the greater part of the manuscript with partial contributions from other co-authors on radar uncertainties and data quality (T. Einfalt); nowcasting, real-time applications and uncertainties (P. Willems); spatial and temporal resolutions (J. E. Nielsen); X-band polarimetry, summary and recommendations (M.-C. ten Veldhuis); offline applications and future outlooks (K. Arnbjerg-Nielsen); technical radar specifications (M. R. Rasmussen); and radar rainfall extremes and proofreading (P. Molnar).

Competing interests. The authors declare that they have no conflict of interest.

Acknowledgements. We acknowledge the International Working Group on Urban Rainfall (IGUR) under the IWA/IAHR Joint Committee on Urban Drainage for providing the network supporting the collaboration in writing this paper. S. Thorndahl acknowledges Damian Murla Tuyls from the Department of Civil Engineering, Aalborg University, for constructive ideas and proofreading as well as David Getreuer Jensen, Envidan A/S, for contributions to the example in Fig. 3.

Edited by: C. Onof

Reviewed by: R. Uijlenhoet and D. Wright

\section{References}

Achleitner, S., Fach, S., Einfalt, T., and Rauch, W.: Nowcasting of rainfall and of combined sewage flow in urban drainage systems, Water Sci. Technol., 59, 1145-1151, doi:10.2166/wst.2009.098, 2009.

Ahm, M., Thorndahl, S., Rasmussen, M. R., and Bassø, L.: Estimating subcatchment runoff coefficients using weather radar and a downstream runoff sensor, Water Sci. Technol., 68, 1293-1299. doi:10.2166/wst.2013.371, 2013.

Anagnostou, M. N. and Anagnostou, E. N.: Precipitation: Advances in Measurement, Estimation and Prediction, edited by: Michaelides, S., Springer Berlin Heidelberg, Berlin, Heidelberg, 2008.

Anagnostou, E. N., Anagnostou, M. N., Krajewski, W. F., Kruger, A., and Miriovsky, B. J.: High-Resolution Rainfall Estimation from X-Band Polarimetric Radar Measurements, J. Hydrometeorol., 5, 110-128, doi:10.1175/15257541(2004)005<0110:HREFXP>2.0.CO;2, 2004.

Atencia, A., Mediero, L., Llasat, M. C., and Garrote, L.: Effect of radar rainfall time resolution on the predictive capability of a distributed hydrologic model, Hydrol. Earth Syst. Sci., 15, 3809 3827, doi:10.5194/hess-15-3809-2011, 2011.

Austin, G. L. and Austin, L. B.: The use of radar in urban hydrology, J. Hydrol., 22, 131-142, doi:10.1016/0022-1694(74)901000,1974

Austin, G. L. and Bellon, A.: The use of digital weather radar records for short-term precipitation forecasting, Q. J. Roy. Meteor. Soc., 100, 658-664, doi:10.1002/qj.49710042612, 1974.

Battan, L. J.: Radar observation of the atmosphere, University of Chicago Press, 1973.

Bell, V. A. and Moore, R. J.: A grid-based distributed flood forecasting model for use with weather radar data: Part 1. Formulation, Hydrol. Earth Syst. Sci., 2, 265-281, doi:10.5194/hess-2265-1998, 1998.

Berenguer, M., Corral, C., Sanchez-Diezma, R., and SempereTorres, D.: Hydrological validation of a radar-based nowcasting technique, J. Hydrometeorol., 6, 532-549, doi:10.1175/JHM433.1, 2005.

Berenguer, M., Sempere-Torres, D., and Pegram, G. G. S.: SBMcast - An ensemble nowcasting technique to assess the uncertainty in rainfall forecasts by Lagrangian extrapolation, J. Hydrol., 404, 226-240, doi:10.1016/j.jhydrol.2011.04.033, 2011.

Berg, P., Norin, L., and Olsson, J.: Creation of a high resolution precipitation data set by merging gridded gauge data and radar observations for Sweden, J. Hydrol., 541, 6-13, doi:10.1016/j.jhydrol.2015.11.031, 2015.

Berndt, C., Rabiei, E., and Haberlandt, U.: Geostatistical merging of rain gauge and radar data for high temporal resolutions and various station density scenarios, J. Hydrol., 508, 88-101, doi:10.1016/j.jhydrol.2013.10.028, 2014.

Berne, A. and Krajewski, W. F.: Radar for hydrology: Unfulfilled promise or unrecognized potential?, Adv. Water Resour., 51, 357-366, doi:10.1016/j.advwatres.2012.05.005, 2013.

Berne, A., Delrieu, G., Creutin, J.-D., and Obled, C.: Temporal and spatial resolution of rainfall measurements required for urban hydrology, J. Hydrol., 299, 166-179, doi:10.1016/j.jhydrol.2004.08.002, 2004.

Borga, M., Anagnostou, E. N., and Frank, E.: On the use of real-time radar rainfall estimates for flood prediction 
in mountainous basins, J. Geophys. Res., 105, 2269-2280, doi:10.1029/1999JD900270, 2000.

Borga, M., Tonelli, F., Moore, R. J., and Andrieu, H.: Long-term assessment of bias adjustment in radar rainfall estimation, Water Resour. Res., 38, 1-10, doi:10.1029/2001WR000555, 2002.

Borup, M., Grum, M., Linde, J. J., and Mikkelsen, P. S.: Dynamic gauge adjustment of high-resolution X-band radar data for convective rain storms: Model-based evaluation against measured combined sewer overflow, J. Hydrol., 539, 687-699, doi:10.1016/j.jhydrol.2016.05.002, 2016.

Bowler, N. E., Pierce, C. E., and Seed, A. W.: STEPS: A probabilistic precipitation forecasting scheme which merges an extrapolation nowcast with downscaled NWP, Q. J. Roy. Meteor. Soc., 132, 2127-2155, doi:10.1256/qj.04.100, 2006.

Brauer, C. C., Overeem, A., Leijnse, H., and Uijlenhoet, R.: The effect of differences between rainfall measurement techniques on groundwater and discharge simulations in a lowland catchment, Hydrol. Process., 30, 3885-3900, doi:10.1002/hyp.10898, 2016.

Bringi, V. N. and Chandrasekar, V.: Polarimetric Doppler Weather Radar, Cambridge University Press, 2001.

Bringi, V. N., Rico-Ramirez, M. A., and Thurai, M.: Rainfall Estimation with an Operational Polarimetric C-Band Radar in the United Kingdom: Comparison with a Gauge Network and Error Analysis, J. Hydrometeorol., 12, 935-954, doi:10.1175/JHM-D10-05013.1, 2011.

Bruni, G., Reinoso, R., van de Giesen, N. C., Clemens, F. H. L. R., and ten Veldhuis, J. A. E.: On the sensitivity of urban hydrodynamic modelling to rainfall spatial and temporal resolution, Hydrol. Earth Syst. Sci., 19, 691-709, doi:10.5194/hess-19-6912015, 2015.

Chumchean, S., Seed, A., and Sharma, A.: Correcting of real-time radar rainfall bias using a Kalman filtering approach, J. Hydrol., 317, 123-137, doi:10.1016/j.jhydrol.2005.05.013, 2006.

Ciach, G. J.: Local random errors in tipping-bucket rain gauge measurements, J. Atmos. Ocean. Tech., 20, 752759, doi:10.1175/1520-0426(2003)20<752:LREITB>2.0.CO;2, 2003.

Ciach, G. J., Morrissey, M.-L., and Krajewski, W. F.: Conditional bias in radar rainfall estimation, J. Appl. Meteorol., 39, 1941-1946, doi:10.1175/15200450(2000)039<1941:CBIRRE>2.0.CO;2, 2000.

Ciach, G. J., Krajewski, W. F., and Villarini, G.: Product-ErrorDriven Uncertainty Model for Probabilistic Quantitative Precipitation Estimation with NEXRAD Data, J. Hydrometeorol., 8, 1325-1347, doi:10.1175/2007JHM814.1, 2007.

Collier, C. G.: Applications of Weather Radar Systems: A Guide to Uses of Radar Data in Meteorology and Hydrology, 2nd ed., Wiley, Chichester, England, 1996.

Delrieu, G., Braud, I., Berne, A., Borga, M., Boudevillain, B., Fabry, F., Freer, J., Gaume, E., Nakakita, E., Seed, A., Tabary, P., and Uijlenhoet, R.: Weather radar and hydrology, Adv. Water Resour., 32, 969-974, doi:10.1016/j.advwatres.2009.03.006, 2009.

Dirckx, G.: EPIGONE: the argus on the daily operation of throttle structures, Water Practice \& Technology, 8, 382-389, doi:10.2166/wpt.2013.038, 2013.

Dixon, M., Li, Z., Lean, H., Roberts, N., and Balland, S.: Impact of data assimilation on forecasting convection over the United Kingdom using a high-resolution version of the met office unified model, Mon. Weather Rev., 137, 1562-1584, doi:10.1175/2008MWR2561.1, 2009.

Dolan, B. and Rutledge, S. A.: Using CASA IP1 to Diagnose Kinematic and Microphysical Interactions in a Convective Storm, Mon. Weather Rev., 138, 1613-1634, doi:10.1175/2009MWR3016.1, 2010.

Dotto, C. B. S., Mannina, G., Kleidorfer, M., Vezzaro, L., Henrichs, M., McCarthy, D. T., Freni, G., Rauch, W., and Deletic, A.: Comparison of different uncertainty techniques in urban stormwater quantity and quality modelling, Water Res., 46, 2545-2558, doi:10.1016/j.watres.2012.02.009, 2012.

Doviak, R. J. and Zrnić, D. S.: Doppler Radar and Weather Observations, Academic San Diego Calif, 33, 562, 1993.

Duncan, A. P., Chen, A. S., Keedwell, E. C., Djordjević, S., and Savić, D. A.: RAPIDS: Early warning system for urban flooding and water quality hazards, in: Machine Learning in Water Systems - AISB Convention 2013, 25-29, 2013.

Einfalt, T. and Luers, S.: Flash Flood warning for emergency warning, in: UrbanRain 15 - 10th International Workshop on Precipitation in Urban Areas "Rainfall in Urban and Natural Systems" Pontresina, Switzerland, 1-5 December, edited by: Molnar, P. and Peleg, N., ETH-Zürich, Institute of Environmental Engineering, 2015.

Einfalt, T., Denoeux, T., and Jacquet, G.: A radar rainfall forecasting method designed for hydrological purposes, J. Hydrol., 114, 229-244, doi:10.1016/0022-1694(90)90058-6, 1990.

Einfalt, T., Arnbjerg-Nielsen, K., Golz, C., Jensen, N.-E., Quirmbach, M., Vaes, G., and Vieux, B.: Towards a roadmap for use of radar rainfall data in urban drainage, J. Hydrol., 299, 186-202, doi:10.1016/j.jhydrol.2004.08.004, 2004.

Einfalt, T., Hatzfeld, F., Wagner, A., Seltmann, J., Castro, D., and Frerichs, S.: URBAS: forecasting and management of flash floods in urban areas, Urban Water J., 6, 369-374, doi:10.1080/15730620902934819, 2009.

Emmanuel, I., Andrieu, H., and Tabary, P.: Evaluation of the new French operational weather radar product for the field of urban hydrology, Atmos. Res., 103, 20-32, 2012a.

Emmanuel, I., Andrieu, H., Leblois, E., and Flahaut, B.: Temporal and spatial variability of rainfall at the urban hydrological scale, J. Hydrol., 430-431, 162-172, doi:10.1016/j.jhydrol.2012.02.013, 2012b.

Fabry, F., Bellon, A., Duncan, M. R., and Austin, G. L.: High resolution rainfall measurements by radar for very small basins: the sampling problem reexamined, J. Hydrol., 161, 415-428, doi:10.1016/0022-1694(94)90138-4, 1994.

Fang, Z., Bedient, P. B., Benavides, J., and Zimmer, A. L.: Enhanced Radar-Based Flood Alert System and Floodplain Map Library, J. Hydrol. Eng., 13, 926-938, doi:10.1061/(ASCE)10840699(2008)13:10(926), 2008.

Faure, D. and Auchet, P.: Real time weather radar data processing for urban hydrology in Nancy, Phys. Chem. Earth Pt. B, 24, $909-$ 914, doi:10.1016/S1464-1909(99)00102-1, 1999.

Foresti, L., Reyniers, M., Seed, A., and Delobbe, L.: Development and verification of a real-time stochastic precipitation nowcasting system for urban hydrology in Belgium, Hydrol. Earth Syst. Sci., 20, 505-527, doi:10.5194/hess-20-505-2016, 2016.

Freni, G., Mannina, G., and Viviani, G.: Uncertainty in urban stormwater quality modelling: The effect of acceptability thresh- 
old in the GLUE methodology, Water Res., 42, 2061-2072, doi:10.1016/j.watres.2007.12.014, 2008.

Fuchs, L. and Beeneken, T.: Development and implementation of a real time control strategy for the sewer system of the city of Vienna, Water Sci. Technol., 52, 187-194, 2005.

Germann, U. and Joss, J.: Variograms of Radar Reflectivity to Describe the Spatial Continuity of Alpine Precipitation, J. Appl. Meteorol., 40, 1042-1059, doi:10.1175/15200450(2001)040<1042:VORRTD>2.0.CO, 2001.

Germann, U., Galli, G., Boscacci, M., and Bolliger, M.: Radar precipitation measurement in a mountainous region, Q. J. Roy. Meteor. Soc., 132, 1669-1692, doi:10.1256/qj.05.190, 2006.

Germann, U., Berenguer, M., Sempere-Torres, D., and Zappa, M.: REAL - Ensemble radar precipitation estimation for hydrology in a mountainous region, Q. J. Roy. Meteor. Soc., 135, 445-456, doi:10.1002/qj.375, 2009.

Gires, A., Onof, C., Maksimovic, C., Schertzer, D., Tchiguirinskaia, I., and Simoes, N.: Quantifying the impact of small scale unmeasured rainfall variability on urban runoff through multifractal downscaling: A case study, J. Hydrol., 442-443, 117-128, doi:10.1016/j.jhydrol.2012.04.005, 2012.

Gires, A., Tchiguirinskaia, I., Schertzer, D., and Lovejoy, S.: Multifractal analysis of a semi-distributed urban hydrological model, Urban Water J., 10, 195-208, doi:10.1080/1573062X.2012.716447, 2013.

Gires, A., Giangola-Murzyn, A., Abbes, J.-B., Tchiguirinskaia, I., Schertzer, D., and Lovejoy, S.: Impacts of small scale rainfall variability in urban areas: a case study with $1 \mathrm{D}$ and 1D/2D hydrological models in a multifractal framework, Urban Water J., 12, 607-617, doi:10.1080/1573062X.2014.923917, 2014a.

Gires, A., Tchiguirinskaia, I., Schertzer, D., Schellart, A., Berne, A., and Lovejoy, S.: Influence of small scale rainfall variability on standard comparison tools between radar and rain gauge data, Atmos. Res., 138, 125-138, doi:10.1016/j.atmosres.2013.11.008, 2014b.

Gjertsen, U., Sálek, M., and Michelson, D. B.: Gauge adjustment of radar-based precipitation estimates in Europe, Proceedings of ERAD Copernicus GmbH, 7-11, 2004.

Goormans, T. and Willems, P.: Using Local Weather Radar Data for Sewer System Modeling: Case Study in Flanders, Belgium, J. Hydrol. Eng., 18, 269-278, doi:10.1061/(ASCE)HE.19435584.0000589, 2013.

Goudenhoofdt, E. and Delobbe, L.: Evaluation of radar-gauge merging methods for quantitative precipitation estimates, Hydrol. Earth Syst. Sci., 13, 195-203, doi:10.5194/hess-13-1952009, 2009.

Goudenhoofdt, E. and Delobbe, L.: Generation and Verification of Rainfall Estimates from 10-Yr Volumetric Weather Radar Measurements, J. Hydrometeorol., 17, 1223-1242, doi:10.1175/JHM-D-15-0166.1, 2016.

Gregersen, I. B., Madsen, H., Rosbjerg, D., and ArnbjergNielsen, K.: Long term variations of extreme rainfall in Denmark and southern Sweden, Clim. Dynam., 44, 3155-3169, doi:10.1007/s00382-014-2276-4, 2014.

Haberlandt, U.: Geostatistical interpolation of hourly precipitation from rain gauges and radar for a largescale extreme rainfall event, J. Hydrol., 332, 144-157, doi:10.1016/j.jhydrol.2006.06.028, 2007.
Haylock, M. R., Hofstra, N., Klein Tank, A. M. G., Klok, E. J., Jones, P. D., and New, M.: A European daily highresolution gridded data set of surface temperature and precipitation for 1950-2006, J. Geophys. Res.-Atmos., 113, 1-12, doi:10.1029/2008JD010201, 2008.

He, X., Vejen, F., Stisen, S., Sonnenborg, T. O., and Jensen., K. H.: An Operational Weather Radar-Based Quantitative Precipitation Estimation and its Application in Catchment Water Resources Modeling, Vadose Zone J., 10, 8, doi:10.2136/vzj2010.0034, 2011.

Henonin, J., Russo, B., Mark, O., and Gourbesville, P.: Real-time urban flood forecasting and modelling - a state of the art, J. Hydroinform., 15, 717, doi:10.2166/hydro.2013.132, 2013.

Hossain, F., Anagnostou, E. N., Dinku, T., and Borga, M.: Hydrological model sensitivity to parameter and radar rainfall estimation uncertainty, Hydrol. Process., 18, 3277-3291, doi:10.1002/hyp.5659, 2004.

Illingworth, A.: Improved Precipitation Rates and Data Quality by Using Polarimetric Measurements, in: Weather radar, edited by: Meischner, P., 130-166, Springer, Berlin, Heidelberg, 2004.

ISO: Meteorology - Ground-based remote sensing of precipitation Weather radar, ISO 19926, 2017.

Jasper-Tönnies, A. and Jessen, M.: Improved radar QPE with temporal interpolation using an advection scheme, in: ERAD 2014 - The eighth European conference on radar in meteorology and hydrology, Garmisch, 1-5 September 2014.

Javier, J. R. N., Smith, J. A., Meierdiercks, K. L., Baeck, M. L., and Miller, A. J.: Flash Flood Forecasting for Small Urban Watersheds in the Baltimore Metropolitan Region, Weather Forecast., 22, 1331-1344, doi:10.1175/2007WAF2006036.1, 2007.

Jensen, D. G., Petersen, C., and Rasmussen, M. R.: Assimilation of radar-based nowcast into a HIRLAM NWP model, Meteorol. Appl., 494, 485-494, doi:10.1002/met.1479, 2015.

Jensen, D. G., Nielsen, J. E., Thorndahl, S., and Rasmussen, M. R.: Ensemble prediction system based on Lagrangian extrapolation of radar derived precipitation (RESEMBLE), in preparation, 2017.

Jessen, M., Einfalt, T., Stoffer, A., and Mehlig, B.: Analysis of heavy rainfall events in North Rhine-Westphalia with radar and raingauge data, Atmos. Res., 77, 337-346, doi:10.1016/j.atmosres.2004.11.031, 2005.

Johnson, D., Smith, M., Koren, V., and Finnerty, B.: Comparing Mean Areal Precipitation Estimates from NEXRAD and Rain Gauge Networks, J. Hydrol. Eng., 4, 117-124, doi:10.1061/(ASCE)1084-0699(1999)4:2(117), 1999.

Johnson, J. T., MacKeen, P. L., Witt, A., Mitchell, E. D. W., Stumpf, G. J., Eilts, M. D., and Thomas, K. W.: The Storm Cell Identification and Tracking Algorithm: An Enhanced WSR-88D Algorithm, Weather Forecast., 13, 263-276, doi:10.1175/15200434(1998)013<0263:TSCIAT>2.0.CO;2, 1998.

Kendon, E., Roberts, N., and Fowler, H.: Heavier summer downpours with climate change revealed by weather forecast resolution model, Nature Climate Change, 4, 1-7, doi:10.1038/NCLIMATE2258, 2014.

Korsholm, U. S., Petersen, C., Sass, B. H., Nielsen, N. W., Jensen, D. G., Olsen, B. T., Gill, R., and Vedel, H.: A new approach for assimilation of $2 \mathrm{D}$ radar precipitation in a high-resolution NWP model, Meteorol. Appl., 22, 48-59, doi:10.1002/met.1466, 2015. 
Krajewski, W. F.: Cokriging radar-rainfall and rain gage data, J. Geophys. Res., 92, 9571, doi:10.1029/JD092iD08p09571, 1987.

Krajewski, W. F. and Smith, J. A.: Radar hydrology: Rainfall estimation, Adv. Water Resour., 25, 1387-1394, doi:10.1016/S03091708(02)00062-3, 2002.

Krajewski, W. F., Villarini, G., and Smith, J. A.: Radar-Rainfall Uncertainties: Where are We after Thirty Years of Effort?, B. Am. Meteorol. Soc., 91, 87-94, doi:10.1175/2009BAMS2747.1, 2010.

Krämer, S., Grum, M., Verworn, H. R., and Redder, A.: Runoff modelling using radar data and flow measurements in a stochastic state space approach, Water Sci. Technol., 52, 1-8, 2005.

Kroll, S., Dirckx, G., Donckels, B. M. R., Van Dorpe, M., Weemaes, M., and Willems, P.: Modelling real-time control of WWTP influent flow under data scarcity, Water Sci. Technol., 73, 16371643, doi:10.2166/wst.2015.641, 2016.

Kuichling, E.: The relation between the rainfall and the discharge of sewers in populous districts, T. Am. Soc. Civ. Eng., 20, 1-56, 1889.

Leijnse, H., Uijlenhoet, R., van de Beek, C. Z., Overeem, A., Otto, T., Unal, C. M. H., Dufournet, Y., Russchenberg, H. W. J., Figueras i Ventura, J., Klein Baltink, H., and Holleman, I.: Precipitation Measurement at CESAR, the Netherlands, J. Hydrometeorol., 11, 1322-1329, doi:10.1175/2010JHM1245.1, 2010.

Lenderink, G.: Exploring metrics of extreme daily precipitation in a large ensemble of regional climate model simulations, Clim. Res., 44, 151-166, doi:10.3354/cr00946, 2010.

Lengfeld, K., Clemens, M., Münster, H., and Ament, F.: Performance of high-resolution X-band weather radar networks the PATTERN example, Atmos. Meas. Tech., 7, 4151-4166, doi:10.5194/amt-7-4151-2014, 2014.

Leonhardt, G., Sun, S., Rauch, W., and Bertrand-Krajewski, J.L.: Comparison of two model based approaches for areal rainfall estimation in urban hydrology, J. Hydrol., 511, 880-890, doi:10.1016/j.jhydrol.2014.02.048, 2014.

Li, L., Schmid, W., and Joss, J.: Nowcasting of Motion and Growth of Precipitation with Radar over a Complex Orography, J. Appl. Meteorol., 34, 1286-1300, doi:0.1175/15200450(1995)034<1286:NOMAGO>2.0.CO;2, 1995.

Liguori, S. and Rico-Ramirez, M. A.: Quantitative assessment of short-term rainfall forecasts from radar nowcasts and MM5 forecasts, Hydrol. Process., 26, 3842-3857, doi:10.1002/hyp.8415, 2012.

Liguori, S. and Rico-Ramirez, M. A.: A review of current approaches to radar-based quantitative precipitation forecasts, International Journal of River Basin Management, 12, 391-402, doi:10.1080/15715124.2013.848872, 2013.

Liguori, S., Rico-Ramirez, M. A., Schellart, A. N. A., and Saul, A. J.: Using probabilistic radar rainfall nowcasts and NWP forecasts for flow prediction in urban catchments, Atmos. Res., 103, 8095, doi:10.1016/j.atmosres.2011.05.004, 2012.

Lobligeois, F., Andréassian, V., Perrin, C., Tabary, P., and Loumagne, C.: When does higher spatial resolution rainfall information improve streamflow simulation? An evaluation using 3620 flood events, Hydrol. Earth Syst. Sci., 18, 575-594, doi:10.5194/hess-18-575-2014, 2014.

Löwe, R., Thorndahl, S., Mikkelsen, P. S., Rasmussen, M. R., and Madsen, H.: Probabilistic online runoff forecasting for urban catchments using inputs from rain gauges as well as statically and dynamically adjusted weather radar, J. Hydrol., 512, 397407, doi:10.1016/j.jhydrol.2014.03.027, 2014.

Löwe, R., Vezzaro, L., Mikkelsen, P. S., Grum, M., and Madsen, H.: Probabilistic runoff volume forecasting in risk-based optimization for RTC of urban drainage systems, Environ. Modell. Softw., 80, 143-158, doi:10.1016/j.envsoft.2016.02.027, 2016.

Madsen, H., Arnbjerg-Nielsen, K., and Mikkelsen, P. S.: Update of regional intensity-duration-frequency curves in Denmark: Tendency towards increased storm intensities, Atmos. Res., 92, 343349, doi:10.1016/j.atmosres.2009.01.013, 2009.

Marra, F. and Morin, E.: Use of radar QPE for the derivation of Intensity-Duration-Frequency curves in a range of climatic regimes, J. Hydrol., 531, 427-440, doi:10.1016/j.jhydrol.2015.08.064, 2015.

Marshall, J. S. and Palmer, W. M.: The distribution of raindrops with size, J. Meteor., 5, 165-166, 1945.

McKee, J. L. and Binns, A. D.: A review of gaugeradar merging methods for quantitative precipitation estimation in hydrology, Can. Water Resour. J., 41, 186-203, doi:10.1080/07011784.2015.1064786, 2016.

Mecklenburg, S., Joss, J., and Schmid, W.: Improving the nowcasting of precipitation in an Alpine region with an enhanced radar echo tracking algorithm, J. Hydrol., 239, 46-68, doi:10.1016/S0022-1694(00)00352-8, 2000.

Meischner, P.: Weather Radar Principles and Advanced Applications, Springer-Verlag Berlin Heidelberg, 2004.

Michaelides, S.: Precipitation: Advances in measurement, estimation and prediction, Springer Berlin Heidelberg, Berlin, Heidelberg, 2008.

Michelson, D., Einfalt, T., Holleman, I., Gjertsen, U., Friedrich, K., Haase, G., Lindskog, M., and Jurczyk, A.: Weather radar data quality in Europe - quality control and characterization, Review, COST Action 717, Luxembourg, ISBN-10: 92-898-00186, 2005.

Mishra, K. V., Krajewski, W. F., Goska, R., Ceynar, D., Seo, B.-C., Kruger, A., Niemeier, J. J., Galvez, M. B., Thurai, M., Bringi, V. N., Tolstoy, L., Kucera, P. A., Petersen, W. A., Grazioli, J., and Pazmany, A. L.: Deployment and Performance Analyses of High-Resolution Iowa XPOL Radar System during the NASA IFloodS Campaign, J. Hydrometeorol., 17, 455-479, doi:10.1175/JHM-D-15-0029.1, 2016.

Mounce, S. R., Shepherd, W., Sailor, G., Shucksmith, J., and Saul, A. J.: Predicting combined sewer overflows chamber depth using artificial neural networks with rainfall radar data, Water Sci. Technol., 69, 1326-1333, doi:10.2166/wst.2014.024, 2014.

Muñoz, C., Wang, L.-P., and Willems, P.: A stochastic spatialtemporal rainfall generator for urban hydrological applications, in: UrbanRain 15 - 10th International Workshop on Precipitation in Urban Areas "Rainfall in Urban and Natural Systems" Pontresina, Switzerland, 1-5 December, edited by: Molnar, P. and Peleg, N., ETH-Zürich, Institute of Environmental Engineering, 2015.

Nielsen, J. E., Rasmussen, M. R., and Thorndahl, S.: What is a proper resolution of weather radar precipitation estimates for urban drainage modelling, IAHS-AISH Publication, 351, 601-606, 2012.

Nielsen, J. E., Jensen, N. E., and Rasmussen, M. R.: Calibrating LAWR weather radar using laser disdrometers, Atmos. Res., 122, 165-173, doi:10.1016/j.atmosres.2012.10.017, 2013. 
Nielsen, J. E., Thorndahl, S., and Rasmussen, M. R.: A numerical method to generate high temporal resolution precipitation time series by combining weather radar measurements with a nowcast model, Atmos. Res., 138, 1-12, doi:10.1016/j.atmosres.2013.10.015, 2014a.

Nielsen, J. E., Beven, K., Thorndahl, S., and Rasmussen, M. R.: GLUE based marine X-band weather radar data calibration and uncertainty estimation, Urban Water J., 12, 283-294, doi:10.1080/1573062X.2013.871044, 2014b.

Nielsen, J. E., Thorndahl, S., and Rasmussen, M. R.: Improving weather radar precipitation estimates by combining two types of radars, Atmos. Res., 139, 36-45, doi:10.1016/j.atmosres.2013.12.013, 2014c.

Nielsen, J. E., Thorndahl, S., and Rasmussen, M. R.: Intercomparison of rainfall measurements from three different types of weather radars covering the same urban area, Proceedings of the 10th International Workshop on Precipitation in Urban Areas (UrbanRain15), 143-144, ETH-Zürich, Institute of Environmental Engineering, doi:10.3929/ethz-a-010549004, 2015.

Ntegeka, V. and Willems, P.: Trends and multidecadal oscillations in rainfall extremes, based on a more than 100-year time series of 10 min rainfall intensities at Uccle, Belgium, Water Resour. Res., 44, 1-15, doi:10.1029/2007WR006471, 2008.

Ntegeka, V., Murla Tuyls, D., Wang, L.-P., Foresti, L., Reyniers, M., Delobbe, L., Van Herck, K., Van Ootegem, L., and Willems, P.: Probabilistic urban inundation nowcasting, in: UrbanRain15 - 10th International Workshop on Precipitation in Urban Areas "Rainfall in Urban and Natural Systems" Pontresina, Switzerland, 1-5 December, edited by: Molnar, P. and Peleg, N., ETHZürich, Institute of Environmental Engineering, 2015.

Ochoa-Rodriguez, S., Wang, L. P., Gires, A., Pina, R. D., ReinosoRondinel, R., Bruni, G., Ichiba, A., Gaitan, S., Cristiano, E., van Assel, J., Kroll, S., Murlà-Tuyls, D., Tisserand, B., Schertzer, D., Tchiguirinskaia, I., Onof, C., Willems, P., and ten Veldhuis, M. C.: Impact of spatial and temporal resolution of rainfall inputs on urban hydrodynamic modelling outputs: A multi-catchment investigation, J. Hydrol., 531, 389-407, doi:10.1016/j.jhydrol.2015.05.035, 2015.

Ochoa Rodriguez, S., Sandford, C., Norman, K., Wang, L., Jewell, S., Akerboom, M., and Onof, C.: Evaluation of the Met Office super-resolution C-band radar rainfall product over London, in: AMS 37th Conference on Radar Meteorology, 14-18 September 2015, Norman, OK, 2015.

Otto, T. and Russchenberg, H. W. J.: Estimation of specific differential phase and differential backscatter phase from polarimetric weather radar measurements of rain, IEEE Geosci. Remote S., 8, 988-992, doi:10.1109/LGRS.2011.2145354, 2011.

Overeem, A., Buishand, T. A., and Holleman, I.: Derivation of a 10-Year Radar-Based Climatology of Rainfall, J. Appl. Meteorol. Climatol., 48, 1448-1463, doi:10.1175/2009JAMC1954.1, 2009a.

Overeem, A., Buishand, T. A., and Holleman, I.: Extreme rainfall analysis and estimation of depth-duration-frequency curves using weather radar, Water Resour. Res., 45, W10424, doi:10.1029/2009WR007869, 2009b.

Overeem, A., Buishand, T. A., Holleman, I., and Uijlenhoet, R.: Extreme value modeling of areal rainfall from weather radar, Water Resour. Res., 46, 1-10, doi:10.1029/2009WR008517, 2010.
Paixao, E., Monirul Qader Mirza, M., Shephard, M. W., Auld, H., Klaassen, J., and Smith, G.: An integrated approach for identifying homogeneous regions of extreme rainfall events and estimating IDF curves in Southern Ontario, Canada: Incorporating radar observations, J. Hydrol., 528, 734-750, doi:10.1016/j.jhydrol.2015.06.015, 2015.

Pedersen, L., Jensen, N. E., and Madsen, H.: Calibration of Local Area Weather Radar - Identifying significant factors affecting the calibration, Atmos. Res., 97, 129-143, doi:10.1016/j.atmosres.2010.03.016, 2010a.

Pedersen, L., Jensen, N. E., Christensen, L. E., and Madsen, H.: Quantification of the spatial variability of rainfall based on a dense network of rain gauges, Atmos. Res., 95, 441-454, doi:10.1016/j.atmosres.2009.11.007, 2010b.

Pegram, G., Llort, X., and Sempere-Torres, D.: Radar rainfall: Separating signal and noise fields to generate meaningful ensembles, Atmos. Res., 100, 226-236, doi:10.1016/j.atmosres.2010.11.018, 2011.

Peleg, N., Blumensaat, F., Molnar, P., Fatichi, S., and Burlando, P.: Partitioning spatial and temporal rainfall variability in urban drainage modelling, Hydrol. Earth Syst. Sci. Discuss., doi:10.5194/hess-2016-530, in review, 2016a.

Peleg, N., Marra, F., Fatichi, S., Paschalis, A., Molnar, P., and Burlando, P.: Spatial variability of extreme rainfall at radar subpixel scale, J. Hydrol., doi:10.1016/j.jhydrol.2016.05.033, in press, $2016 b$.

Pfister, A. and Cassar, A.: Use and benefit of radar rainfall data in an urban real time control project, Phys. Chem. Earth Pt. B, 24, 903-908, doi:10.1016/S1464-1909(99)00101-X, 1999.

Quirmbach, M. and Schultz, G. A.: Use of weather radar for combined control of an urban drainage system and a sewage treatment plant, Urban Water, 259, 245-250, 1999.

Quirmbach, M. and Schultz, G. A.: Comparison of rain gauge and radar data as input to an urban rainfall-runoff model, Water Sci. Technol., 45, 27-33, 2002.

Rabiei, E. and Haberlandt, U.: Applying bias correction for merging rain gauge and radar data, J. Hydrol., 522, 544-557, doi:10.1016/j.jhydrol.2015.01.020, 2015.

Rafieeinasab, A., Norouzi, A., Kim, S., Habibi, H., Nazari, B., Seo, D. J., Lee, H., Cosgrove, B., and Cui, Z.: Toward high-resolution flash flood prediction in large urban areas Analysis of sensitivity to spatiotemporal resolution of rainfall input and hydrologic modeling, J. Hydrol., 531, 370-388, doi:10.1016/j.jhydrol.2015.08.045, 2015.

Raut, B. A., De La Fuente, L., Seed, A. W., Jakob, C., and Reeder, M. J.: Application of a space-time stochastic model for downscaling future rainfall projections, in: Proceedings of the 34th Hydrology and Water Resources Symposium, HWRS, 19-22 November 2012, 579-586, 2012.

Rico-Ramirez, M. A., Liguori, S., and Schellart, A. N. A.: Quantifying radar-rainfall uncertainties in urban drainage flow modelling, J. Hydrol., 528, 17-28, doi:10.1016/j.jhydrol.2015.05.057, 2015.

Rinehart, R. E.: Radar for Meteorologists, 5th ed., Rinehart Publications, 2010.

Rinehart, R. E. and Garvey, E. T.: Three-dimensional storm motion detection by conventional weather radar, Nature, 273, 287-289, doi:10.1038/273287a0, 1978.

Scarchilli, G., Goroucci, E., Chandrasekar, V., and Seliga, T. A.: Rainfall Estimation Using Polarimetric Techniques at 
C-Band Frequencies, J. Appl. Meteorol., 32, 1150-1160, doi:10.1175/1520-0450(1993)032<1150:REUPTA >2.0.CO;2, 1993.

Schellart, A., Liguori, S., Krämer, S., Saul, A., and Rico-Ramirez, M.: Analysis of different quantitative precipitation forecast methods for runoff and flow prediction in a small urban area, IAHSAISH Publication, 351, 614-619, 2012a.

Schellart, A. N. A., Shepherd, W. J., and Saul, A. J.: Influence of rainfall estimation error and spatial variability on sewer flow prediction at a small urban scale, Adv. Water Resour., 45, 65-75, doi:10.1016/j.advwatres.2011.10.012, 2012b.

Schellart, A., Liguori, S., Krämer, S., Saul, A., and Rico-Ramirez, M.: Comparing quantitative precipitation forecast methods for prediction of sewer flows in a small urban area, Hydrolog. Sci. J., 59, 1418-1436, doi:10.1080/02626667.2014.920505, 2014.

Schilling, W.: Rainfall data for urban hydrology: what do we need?, Atmos. Res., 27, 5-21, doi:10.1016/0169-8095(91)90003-F, 1991.

Schütze, M., Campisano, A., Colas, H., Schilling, W., and Vanrolleghem, P. A.: Real time control of urban wastewater systems - Where do we stand today?, J. Hydrol., 299, 335-348, doi:10.1016/j.jhydrol.2004.08.010, 2004.

Seo, D.-J. and Breidenbach, J. P.: Real-Time Correction of Spatially Nonuniform Bias in Radar Rainfall Data Using Rain Gauge Measurements, J. Hydrometeorol., 3, 93-111, doi:10.1175/15257541(2002)003<0093:RTCOSN>2.0.CO;2, 2002.

Seo, B.-C. and Krajewski, W. F.: Scale Dependence of Radar Rainfall Uncertainty: Initial Evaluation of NEXRAD's New SuperResolution Data for Hydrologic Applications, J. Hydrometeorol., 11, 1191-1198, doi:10.1175/2010JHM1265.1, 2010.

Seo, B. C. and Krajewski, W. F.: Correcting temporal sampling error in radar-rainfall: Effect of advection parameters and rain storm characteristics on the correction accuracy, J. Hydrol., 531, 272283, doi:10.1016/j.jhydrol.2015.04.018, 2015.

Seo, D.-J., Breidenbach, J., and Johnson, E.: Real-time estimation of mean field bias in radar rainfall data, J. Hydrol., 223, 131-147, doi:10.1016/S0022-1694(99)00106-7, 1999.

Sharif, H. O. and Ogden, F. L.: Mass-Conserving Remapping of Radar Data onto Two-Dimensional Cartesian Coordinates for Hydrologic Applications, J. Hydrometeorol., 15, 2190-2202, doi:10.1175/JHM-D-14-0058.1, 2014.

Sharif, H. O., Yates, D., Roberts, R., and Mueller, C.: The Use of an Automated Nowcasting System to Forecast Flash Floods in an Urban Watershed, J. Hydrometeorol., 7, 190-202, doi:10.1175/JHM482.1, 2006.

Sideris, I. V., Gabella, M., Erdin, R., and Germann, U.: Real-time radar-rain-gauge merging using spatio-temporal co-kriging with external drift in the alpine terrain of Switzerland, Q. J. Roy. Meteor. Soc., 140, 1097-1111, doi:10.1002/qj.2188, 2014.

Sinclair, S. and Pegram, G.: Combining radar and rain gauge rainfall estimates using conditional merging, Atmos. Sci. Lett., 6, 19-22, doi:10.1002/asl.85, 2005.

Sivapalan, M. and Blöschl, G.: Transformation of point rainfall to areal rainfall: Intensity-duration-frequency curves, J. Hydrol., 204, 150-167, doi:10.1016/S0022-1694(97)00117-0, 1998.

Smith, B. K., Smith, J. A., Baeck, M. L., Villarini, G., and Wright, D. B.: Spectrum of storm event hydrologic response in urban watersheds, Water Resour. Res., 49, 2649-2663, doi:10.1002/wrcr.20223, 2013.
Smith, J. A. and Krajewski, W. F.: Estimation of the mean field bias of radar rainfall estimates, J. Appl. Meteorol., 30, 397-412, 1991.

Smith, J. A., Baeck, M. L., Morrison, J. E., Sturdevant-Rees, P., Turner-Gillespie, D. F., and Bates, P. D.: The Regional Hydrology of Extreme Floods in an Urbanizing Drainage Basin, J. Hydrometeorol., 3, 267-282, doi:10.1175/15257541(2002)003<0267:TRHOEF>2.0.CO;2, 2002.

Smith, J. A., Baeck, M. L., Meierdiercks, K. L., Miller, A. J., and Krajewski, W. F.: Radar rainfall estimation for flash flood forecasting in small urban watersheds, Adv. Water Resour., 30, 2087 2097, doi:10.1016/j.advwatres.2006.09.007, 2007.

Sørup, H. J. D., Christensen, O. B., Arnbjerg-Nielsen, K., and Mikkelsen, P. S.: Downscaling future precipitation extremes to urban hydrology scales using a spatio-temporal Neyman-cott weather generator, Hydrol. Earth Syst. Sci., 20, 1387-1403, doi:10.5194/hess-20-1387-2016, 2016.

Stephan, K., Klink, S., and Schraff, C.: Assimilation of radarderived rain rates into the convective-scale model COSMODE at DWD, Q. J. Roy. Meteor. Soc., 134, 1315-1326, doi:10.1002/qj.269, 2008.

Tabari, H., De Troch, R., Giot, O., Hamdi, R., Termonia, P., Saeed, S., Brisson, E., Van Lipzig, N., and Willems, P.: Local impact analysis of climate change on precipitation extremes: are highresolution climate models needed for realistic simulations?, Hydrol. Earth Syst. Sci., 20, 3843-3857, doi:10.5194/hess-20-38432016, 2016.

Thorndahl, S. and Rasmussen, M. R.: Marine X-band weather radar data calibration, Atmos. Res., 103, 33-44, doi:10.1016/j.atmosres.2011.04.023, 2012.

Thorndahl, S. and Rasmussen, M. R.: Short-term forecasting of urban storm water runoff in real-time using extrapolated radar rainfall data, J. Hydroinform., 15, 897-912, 2013.

Thorndahl, S. and Willems, P.: Probabilistic modelling of overflow, surcharge and flooding in urban drainage using the first-order reliability method and parameterization of local rain series, Water Res., 42, 455-466, doi:10.1016/j.watres.2007.07.038, 2008.

Thorndahl, S., Johansen, C., and Schaarup-Jensen, K.: Assessment of runoff contributing catchment areas in rainfall runoff modelling, Water Sci. Technol., 54, 49-56, doi:10.2166/wst.2006.621, 2006.

Thorndahl, S., Beven, K. J., Jensen, J. B., and Schaarup-Jensen, K.: Event based uncertainty assessment in urban drainage modelling, applying the GLUE methodology, J. Hydrol., 357, 421437, doi:10.1016/j.jhydrol.2008.05.027, 2008.

Thorndahl, S., Poulsen, T. S., Bøvith, T., Borup, M., Ahm, M., Nielsen, J. E., Grum, M., Rasmussen, M. R., Gill, R., and Mikkelsen, P. S.: Comparison of short-term rainfall forecasts for modelbased flow prediction in urban drainage systems, Water Sci. Technol., 68, 472-478, doi:10.2166/wst.2013.274, 2013.

Thorndahl, S., Smith, J. A., Baeck, M. L., and Krajewski, W. F.: Analyses of the temporal and spatial structures of heavy rainfall from a catalog of high-resolution radar rainfall fields, Atmos. Res., 144, 111-125, doi:10.1016/j.atmosres.2014.03.013, 2014a.

Thorndahl, S., Nielsen, J. E., and Rasmussen, M. R.: Bias adjustment and advection interpolation of long-term high resolution radar rainfall series, J. Hydrol., 508, 214-226, doi:10.1016/j.jhydrol.2013.10.056, 2014b.

Thorndahl, S., Nielsen, J. E., and Jensen, D. G.: Urban pluvial flood prediction: a case study evaluating radar rainfall nowcasts and 
numerical weather prediction models as model inputs, Water Sci. Technol., 74, 2599-2610, doi:10.2166/wst.2016.474, 2016.

Tilford, K. A., Fox, N. I., and Collier, C. G.: Application of weather radar data for urban hydrology, Meteorol. Appl., 9, 95-104, doi:10.1017/S135048270200110X, 2002.

Todini, E.: A Bayesian technique for conditioning radar precipitation estimates to rain-gauge measurements, Hydrol. Earth Syst. Sci., 5, 187-199, doi:10.5194/hess-5-187-2001, 2001.

Turner, B. J., Zawadzki, I., and Germann, U.: Predictability of precipitation from continental radar images. Part III: Operational nowcasting implementation (MAPLE), J. Appl. Meteorol., 43, 231-248, doi:10.1175/15200450(2004)043<0231:POPFCR>2.0.CO;2, 2004.

Uijlenhoet, R.: Raindrop size distributions and radar reflectivityrain rate relationships for radar hydrology, Hydrol. Earth Syst. Sci., 5, 615-628, doi:10.5194/hess-5-615-2001, 2001.

Vaes, G., Willems, P., and Berlamont, J.: Areal rainfall correction coefficients for small urban catchments, Atmos. Res., 77, 48-59, doi:10.1016/j.atmosres.2004.10.015, 2005.

van de Beek, C. Z., Leijnse, H., Stricker, J. N. M., Uijlenhoet, R., and Russchenberg, H. W. J.: Performance of high-resolution Xband radar for rainfall measurement in The Netherlands, Hydrol. Earth Syst. Sci., 14, 205-221, doi:10.5194/hess-14-205-2010, 2010.

van de Beek, C. Z., Leijnse, H., Torfs, P. J. J. F., and Uijlenhoet, R.: Seasonal semi-variance of Dutch rainfall at hourly to daily scales, Adv. Water Resour., 45, 76-85, doi:10.1016/j.advwatres.2012.03.023, 2012.

Van Ootegem, L., Van Herck, K., Creten, T., Verhofstadt, E., Foresti, L., Goudenhoofdt, E., Reyniers, M., Delobbe, L., Murla Tuyls, D., and Willems, P.: Exploring the potential of multivariate depth-damage and rainfall-damage models, Journal of Flood Risk Management, doi:10.1111/jfr3.12284, in press, 2017.

VDI: Environmental meteorology - Ground-based remote sensing of precipitation - Weather radar, VDI 3786 Part 20, Beuth Verlag, Berlin, 2014.

Velasco-Forero, C. A., Sempere-Torres, D., Cassiraga, E. F., and Jaime Gómez-Hernández, J.: A non-parametric automatic blending methodology to estimate rainfall fields from rain gauge and radar data, Adv. Water Resour., 32, 986-1002, doi:10.1016/j.advwatres.2008.10.004, 2009.

Vezzaro, L. and Grum, M.: A generalised Dynamic Overflow Risk Assessment (DORA) for Real Time Control of urban drainage systems, J. Hydrol., 515, 292-303, doi:10.1016/j.jhydrol.2014.05.019, 2014.

Vieux, B. E. and Bedient, P. B.: Assessing urban hydrologic prediction accuracy through event reconstruction, J. Hydrol., 299, 217-236, doi:10.1016/j.jhydrol.2004.08.005, 2004a.

Vieux, B. E. and Bedient, P. B.: Evaluation of urban hydrologic prediction accuracy for real-time forecasting using radar-rainfall, in: Bulletin of the American Meteorological Society, Combined Preprints: 84th American Meteorological Society (AMS) Annual Meeting, Seattle, WA, USA, 11-15 January 2004, Code 62939, 587-592, 2004b.

Vieux, B. E. and Imgarten, J. M.: On the scale-dependent propagation of hydrologic uncertainty using high-resolution X-band radar rainfall estimates, Atmos. Res., 103, 96-105, doi:10.1016/j.atmosres.2011.06.009, 2012.
Vieux, B. E., Imgarten, J. M., Looper, J. P., and Bedient, P. B.: Radar-Based Flood Forecasting: Quantifying Hydrologic Prediction Uncertainty in Urban-Scale Catchments for CASA Radar Deployment, in World Environmental and Water Resources Congress 2008, 316, 1-10, American Society of Civil Engineers, Reston, VA, 2008.

Villarini, G. and Krajewski, W. F.: Review of the different sources of uncertainty in single polarization radar-based estimates of rainfall, Surv. Geophys., 31, 107-129, doi:10.1007/s10712-0099079-x, 2010.

Villarini, G., Serinaldi, F., and Krajewski, W. F.: Modeling radarrainfall estimation uncertainties using parametric and nonparametric approaches, Adv. Water Resour., 31, 1674-1686, doi:10.1016/j.advwatres.2008.08.002, 2008a.

Villarini, G., Mandapaka, P. V., Krajewski, W. F., and Moore, R. J.: Rainfall and sampling uncertainties: A rain gauge perspective, J. Geophys. Res.-Atmos., 113, 1-12, doi:10.1029/2007JD009214, 2008b.

Villarini, G., Smith, J. A., Lynn Baeck, M., Sturdevant-Rees, P., and Krajewski, W. F.: Radar analyses of extreme rainfall and flooding in urban drainage basins, J. Hydrol., 381, 266-286, doi:10.1016/j.jhydrol.2009.11.048, 2010.

Villarini, G., Seo, B. C., Serinaldi, F., and Krajewski, W. F.: Spatial and temporal modeling of radar rainfall uncertainties, Atmos. Res., 135-136, 91-101, doi:10.1016/j.atmosres.2013.09.007, 2014.

Wang, L.-P., Ochoa-Rodríguez, S., Simões, N. E., Onof, C., and Maksimović, C.: Radar-raingauge data combination techniques: a revision and analysis of their suitability for urban hydrology, Water Sci. Technol., 68, 737-747, doi:10.2166/wst.2013.300, 2013.

Wang, L.-P., Ochoa-Rodríguez, S., Van Assel, J., Pina, R. D., Pessemier, M., Kroll, S., Willems, P., and Onof, C.: Enhancement of radar rainfall estimates for urban hydrology through optical flow temporal interpolation and Bayesian gauge-based adjustment, J. Hydrol., 531, 408-426, doi:10.1016/j.jhydrol.2015.05.049, 2015a.

Wang, L.-P., Ochoa-Rodríguez, S., Onof, C., and Willems, P.: Singularity-sensitive gauge-based radar rainfall adjustment methods for urban hydrological applications, Hydrol. Earth Syst. Sci., 19, 4001-4021, doi:10.5194/hess-19-4001-2015, 2015b.

Wang, L. P., Simões, N., Rico-Ramirez, M., Ochoa, S., Leitão, J., and Maksimovič, Č.: Radar-based pluvial flood forecasting over urban areas: Redbridge case study, IAHS-AISH Publication, 351, 632-637, 2012.

Willems, P.: Stochastic description of the rainfall input errors in lumped hydrological models, Stoch. Env. Res. Risk A., 15, 132 152, doi:10.1007/s004770000063, 2001.

Willems, P.: Quantification and relative comparison of different types of uncertainties in sewer water quality modeling, Water Res., 42, 3539-3551, doi:10.1016/j.watres.2008.05.006, 2008.

Willems, P.: Multidecadal oscillatory behaviour of rainfall extremes in Europe, Climatic Change, 120, 931-944, doi:10.1007/s 10584013-0837-x, 2013a.

Willems, P.: Revision of urban drainage design rules after assessment of climate change impacts on precipitation extremes at Uccle, Belgium, J. Hydrol., 496, 166-177, doi:10.1016/j.jhydrol.2013.05.037, 2013b. 
Willems, P. and Berlamont, J.: Probabilistic modelling of sewer system overflow emissions, Water Sci. Technol., 39, 47-54, 1999.

Wilson, J. W. and Brandes, E. A.: Radar measurement of rainfall a summary, B. Am. Meteorol. Soc., 60, 1048-1058, 1979.

WMO: The Guide to Hydrological Practices. Volume I Hydrology From Measurement to Hydrological Information WMO-No. 168, World Meteorological Organization, 2008.

Wolfs, V. and Willems, P.: Modular Conceptual Modelling Approach and Software for Sewer Hydraulic Computations, Water Resour. Manag., 31, 283-298, doi:10.1007/s11269-016-1524-2, 2017.

Wright, D. B., Smith, J. A., Villarini, G., and Baeck, M. L.: Hydroclimatology of flash flooding in Atlanta, Water Resour. Res., 48, 1-14, doi:10.1029/2011WR011371, 2012.

Wright, D. B., Smith, J. A., and Baeck, M. L.: Critical Examination of Area Reduction Factors, J. Hydrol. Eng., 19, 769-776, doi:10.1061/(ASCE)HE.1943-5584.0000855, 2014a.

Wright, D. B., Smith, J. A., and Baeck, M. L.: Flood frequency analysis using radar rainfall fields and stochastic storm transposition, Water Resour. Res., 50, 1592-1615, doi:10.1002/2013WR014224, 2014b.
Wright, D. B., Smith, J. A., Villarini, G., and Baeck, M. L.: Long-Term High-Resolution Radar Rainfall Fields for Urban Hydrology, J. Am. Water Resour. As., 50, 713-734, doi:10.1111/jawr.12139, 2014c.

Yang, L., Smith, J. A., Wright, D. B., Baeck, M. L., Villarini, G., Tian, F., and $\mathrm{Hu}, \mathrm{H} .:$ Urbanization and Climate Change: An Examination of Nonstationarities in Urban Flooding, J. Hydrometeorol., 14, 1791-1809, doi:10.1175/JHM-D-12-095.1, 2013.

Yuan, J. M., Tilford, K. A., Jiang, H. Y., and Cluckie, I. D.: Real-time urban drainage system modelling using weather radar rainfall data, Phys. Chem. Earth Pt. B, 24, 915-919, doi:10.1016/S1464-1909(99)00103-3, 1999.

Zhou, Q., Mikkelsen, P. S., Halsnæs, K., and Arnbjerg-Nielsen, K.: Framework for economic pluvial flood risk assessment considering climate change effects and adaptation benefits, J. Hydrol., 414-415, 539-549, doi:10.1016/j.jhydrol.2011.11.031, 2012. 